\title{
NEW GINKGOPHYTES FROM THE UPPER TRIASSIC-LOWER CRETACEOUS OF SPITSBERGEN AND EDGEØYA (SVALBARD, ARCTIC NORWAY): THE HISTORY OF GINKGOALES ON SVALBARD
}

\author{
Christian Pott, ${ }^{1, *}$ Johan van der Burgh, $†$ and Johanna H. A. van Konijnenburg-van Cittertt’ \\ *Department of Palaeobiology, Swedish Museum of Natural History, Box 50007, 10405 Stockholm, Sweden; \\ +Laboratory of Palaeobotany and Palynology, Heidelberglaan 2, 3584 CS Utrecht, The Netherlands; and \\ ¥Naturalis Biodiversity Center, PO Box 9517, 2300 RA Leiden, The Netherlands
}

Editor: Patrick S. Herendeen

\begin{abstract}
Premise of research. During the ongoing investigation of Upper Triassic-Lower Cretaceous plant macrofossils from Svalbard, Norway, some ginkgoalean leaf fossils were found from Carnian and Aptian deposits of Spitsbergen and Edgeøya that represent new ginkgophyte species. One new species is described as Baiera aquilonia sp. nov., and one ginkgophyte leaf is assigned to Ginkgoites sp. Along with the description of the new material, an overview of the presence and distribution of ginkgophytes in the high-latitude ecosystems of Svalbard through time is provided.

Methodology. The plant macrofossils have been analyzed with transmitted-light and epifluorescence microscopy. Attempts to isolate cuticles were made.

Pivotal results. The investigation resulted in the description of one species new to science, Baiera aquilonia sp. nov., and one specimen assigned to Ginkgoites sp. The presence of ginkgophytes on Svalbard changed significantly through time: periods of dominance and wide distribution interchanged with periods of very low diversity and abundance.

Conclusions. Ginkgophytes were thriving in Svalbard, which was already located above $60^{\circ} \mathrm{N}$ by the Carnian, from the Late Triassic to the Cenozoic in varying abundance and were finally extirpated, probably as a result of dramatic climatic changes at the end of the Paleogene.
\end{abstract}

Keywords: Arctic, Ginkgo, Ginkgoites, Baiera aquilonia, Sphenobaiera, Carnian, Cretaceous, Cenozoic.

\section{Introduction}

Ginkgophytes (Ginkgoales) today comprise only one extant species, Ginkgo biloba L., which survived extinction in two provinces in southwestern China (Chongqing and Guizhou), with extended range to southern Gansu and northern Guangdong (Lin 2007; Zhou 2009). Its original distribution area is assumed to have been located in the mesophytic forests on the hills along the Yangtze River. Modern Ginkgo L. trees are relatively undemanding and resistant to pest infestation, making them preferred ornamental trees in various regions and cities of the world. The fossil history of Ginkgoales shows that the group was much more diverse during its long evolutionary history, being a major part of the vegetation in several regions. Ginkgoales were distributed almost all over the world from the Late Permian to the Early Cenozoic, including the Nordic archipelago of Svalbard (see, e.g., Villar de Seoane et al. 2015).

\footnotetext{
1 Author for correspondence; e-mail: christian.pott@nrm.se.
}

Manuscript received April 2015; revised manuscript received July 2015; electronically published January 8, 2016.
Svalbard is known today as a more or less hostile arctic environment consisting of rocky terrain and sandy and pebbly beaches, and most inland areas are covered with glaciers and ice. Today's vegetation is a typical Arctic tundra; it comprises about 164 species of vascular plants (Rønning 1996; Sandbakk 2015), which is, considering the position of Svalbard so far north, an astonishing variety of plant life. A low number of woody plants cope with the Arctic environment, but these are exclusively angiosperms; gymnosperms are absent from Svalbard today. Svalbard has been located above $60^{\circ} \mathrm{N}$ from the Triassic onward, but climate and vegetation have changed much during the archipelago's geological history.

Plant fossils are known from Upper Triassic (Carnian) to Lower Cenozoic deposits from almost all parts of Svalbard (fig. 1; Heer 1870; Nathorst 1897, 1921; Schloemer-Jäger 1958; Kvaček and Manum 1997; Denk et al. 1999; Pott 2014b); among these are several ginkgophytes. They were thriving on Svalbard in changing abundance but had their distribution and abundance heyday during the Lower Cretaceous (e.g., Heer 1876b; Nathorst 1897; C. Pott, unpublished data). Even if only four species were recorded in the genera Ginkgoites Seward, Pseudotorellia Florin, and Sphenobaiera Florin, they were widely distributed, represented by a relatively high abundance of fossils, comparable with 


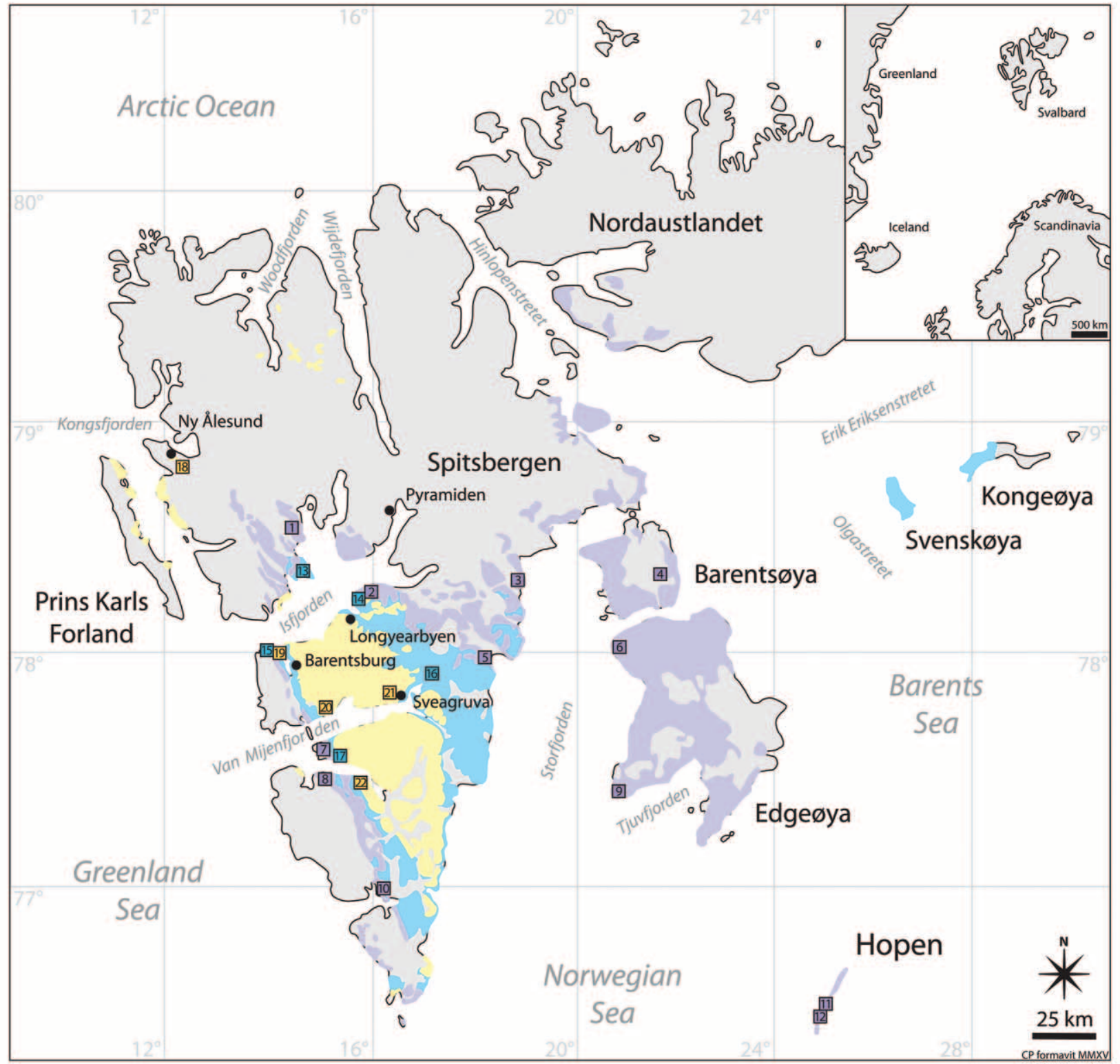

Fig. 1 Map of Svalbard with the localities mentioned in the text (lilac: De Geerdalen Formation, Carnian; blue: Helvetiafjellet and Carolinefjellet Formations, Barremian-Aptian; yellow: Firkanten and Basilika Formations, Paleocene) and rough distribution of Triassic (lilac), Jurassic/Cretaceous (blue), and Cenozoic (yellow) deposits. Locality names: 1, Bertilryggen; 2, Wimanfjellet; 3, Teistberget; 4, Schweinfurthberget; 5, Agardhbukta; 6, Kapp Lee; 7, Midterhukfjellet; 8, Fleur de Lyshamna; 9, Kvalpynten; 10, Hyrnefjellet; 11, Kollerfjellet; 12, Gåsskaret; 13, Bohemanneset; 14, Hanaskogdalen; 15, Festningsodden; 16, Langstakken; 17, Ulladalen; 18, Brøggerhalvøya; 19, Grønfjorden; 20, Kolfjellet; 21, Liljevalchfjellet; 22, Basilika.

other floras from the Early Cretaceous (e.g., Florin 1936a, 1936b; Samylina 1956a, 1956b; Watson et al. 1999; Pott et al. 2014). Earlier, during the Late Triassic, abundance and diversity were much lower, with three species in two genera (Arberophyllum Doweld and Ginkgoites), represented by a moderate number of fossils from all over Svalbard (Pott 2014b). For the Tertiary, ginkgophytes (e.g., Ginkgo) occur only sporadically on Svalbard (Heer 1870; Nathorst 1921; Schloemer-Jäger 1958; Manum 1966; Kvaček and Manum 1997); only one species has been recorded (Ginkgo spitsbergensis Manum), with moderate abundance but restricted to a limited number of localities. The modern-day flora of Svalbard does not include any ginkgophytes (Rønning 1996;
Sandbakk 2015). At which geological epoch ginkgophytes and other gymnospermous seed plants finally disappeared from Svalbard is difficult to ascertain.

In this article, we describe two new ginkgophytes from the Carnian of Kvalpynten on Edgeøya and the Aptian of Bohemanneset on Spitsbergen. The Late Triassic flora of Svalbard has recently been revised in detail (Pott 2014b), but subsequently, unstudied and new material appeared from collections and recent field trips, leading to the description of several new species for Svalbard and some new to science (Launis et al. 2014; Pott and Launis 2015). The Early Cretaceous flora from Svalbard is currently under investigation by C. Pott. Among these fossils, 
we detected the ginkgophytes described here. In addition, we provide a synopsis and critical review of all ginkgophytes that have been reported so far from Svalbard.

\section{Material, Methods, and Geology}

The study is based on specimens that were recently discovered among specimens from Svalbard stored in the collections of the Laboratory of Palaeobotany and Palynology (LPP), Utrecht University, Utrecht, Netherlands. The specimens are available under accession numbers LPP 24212 and LPP 353 (with its counterpart G.333.1922, from the collection of the Utrecht University Museum, currently stored at the LPP). The first was found among specimens that were collected during an ecological excursion from the University of Utrecht in 1969 at the western tip of Edgeøya, Svalbard, which is known as Kvalpynten (Whales Point; NPI 2015b), and the latter came from a historical collection studied by I. Swemle in 1922; that material was found at Bohemanneset, located on the northern shore of Isfjorden, western Spitsbergen. The identity of the collectors of the specimens is unknown.

The fossil specimens serving for the synopsis and review of the remaining ginkgophytes from Svalbard described below are stored in the palaeobotanical collections of the Swedish $\mathrm{Mu}$ seum of Natural History (NRM), Stockholm, Sweden, the LPP, and the A. P. Karpinsky Russian Geological Research Institute (VSEGEI), St. Petersburg, Russian Federation. The specimens stored at the latter were accessed in November 2011 (see Pott 2014b), whereas the material at NRM and LPP is permanently available and was accessed during this research.

The specimens were analyzed with a ZEISS Stemi SV11 dissecting microscope and photographed with a Nikon D80/Nikkor AF-S Mikro 60-mm 1:2.8G ED system digital camera. Oblique lightning and polarizing filters in front of the camera lens and the lights were used to enhance contrast and fine details of the venation and leaf surface.

An attempt to isolate cuticle with the standard maceration procedures as outlined, e.g., in Pott and McLoughlin (2009) and Pott $(2014 a)$ was unsuccessful; analyzing the specimen LPP 24212 with an Olympus BX-51 light microscope, which was modified for epifluorescence microscopy, did not reveal any fluorescing cuticles. The specimen from Bohemanneset was lacquered, and hence study of epidermal details was not possible.

The fossil LPP 24212 comes from an undifferentiated formation at Kvalpynten on Edgeøya, the third-largest island of the Svalbard Archipelago, situated to the east of Spitsbergen and south of Barentsøya (fig. 1). The entire area of Kvalpynten $\left(77^{\circ} 26^{\prime} 33^{\prime \prime} \mathrm{N}\right.$, $20^{\circ} 52^{\prime} 28^{\prime \prime} \mathrm{E}$ ) is characterized by sediments that are allocated to the Kapp Toscana Group, which consists of sediments that were deposited from the Late Triassic to the Early Jurassic. From its texture and composition, this formation on Edgeøya is largely identical to deposits that are identified as the De Geerdalen Formation on Spitsbergen. The deposits on Edgeøya and Barentsøya have been interpreted as belonging to the De Geerdalen and Tschermakfjellet Formations (Mørk et al. 1982). The De Geerdalen Formation is dated as Carnian but also extends into the Norian (e.g., Tozer and Parker 1968; Dypvik et al. 1985; Dobruskina 1994; Dallmann et al. 2001; Hounslow et al. 2007; Vigran et al. 2014). In some parts of Svalbard, the Kapp Toscana Group is not differentiated into constituent formations (Mørk et al. 1982; Dallmann et al. 2001; Hounslow et al. 2007), as is the case on Edgeøya, where geological mapping and prospecting are not yet complete (NPI 2015a). The plant fossils usually occur in two beds of the De Geerdalen Formation, which are dated as late Carnian on the basis of palynology (Vigran et al. 2014). For a more detailed overview of the stratigraphy and dating of the Upper Triassic sediments on Svalbard, see Pott (2014b) and Vigran et al. (2014). The specimens accompanying the one under study yielded elements from typical Carnian floras from all over Svalbard, such as Asterotheca merianii Stur ex Krasser; Dictyophyllum exile (Brauns) Nathorst; Taeniopteris novomundensis Pott and Launis; Nilssoniopteris angustior (Stur ex Krasser) Pott, Krings and Kerp; Pterophyllum filicoides (Schlotheim) Zeiller; and Pterophyllum firmifolium Ye ex Wu, Ye and Li (C. Pott, J. H. A. van Konijnenburg-van Cittert, and J. van der Burgh, personal observation, July 5, 2014; cf. Pott 2014b; Pott and Launis 2015).

The specimen LPP 353 comes from the Helvetiafjellet Formation (Glitrefjellet Member) on the northern shore of Isfjorden at Bohemanneset (fig. 1). The entire area of Bohemanneset $\left(78^{\circ} 23^{\prime} 15^{\prime \prime} \mathrm{N}, 14^{\circ} 45^{\prime} 08^{\prime \prime} \mathrm{E}\right)$ is characterized by sediments that are allocated to the Adventdalen Group, which consists of sediments that were deposited from the Jurassic to the Cretaceous. The Helvetiafjellet Formation is dated as Barremian-Aptian; the Early Aptian Glitrefjellet Member overlies the Barremian Festningen Member that constitutes the lower part of the Helvetiafjellet Formation (e.g., Parker 1967; Mørk 1978; Harland 1997). It has been interpreted as an interdigitated deltaic facies (Steel et al. 1978; Gjelberg and Steel 1995).

The age of the deposits where the species reviewed in our synopsis below originate has been determined from literature research (e.g., Harland 1997) and comparison with detailed geological maps provided by the Norsk Polarinstitutt, Tromsø, Norway. The geological setting and age of these deposits are not reviewed here in detail, and the interested reader is referred to the respective literature outlined, e.g., in Harland (1997) or Vigran et al. (2014).

\section{Results}

In the following paragraphs, we describe specimens from the Carnian and Aptian deposits of Spitsbergen and Edgeøya that represent previously unknown foliage, including one species new to science. Subsequently, we present a chronologic and systematic overview of all ginkgophytes recorded from Svalbard.

\section{Systematic Paleobotany}

New species. Two new ginkgoalean taxa have recently been identified among specimens collected from Kvalpynten, Edgeøya (Ginkgoites sp.), and Bohemanneset, Spitsbergen (Baiera aquilonia).

\section{Ginkgophyta}

Order-Ginkgoales Gorozhankin

Family - Ginkgoaceae Engler in Engler and Prantl

Genus-Ginkgoites Seward

Ginkgoites is characterized by fan-shaped leaves that resemble leaves of modern-day Ginkgo biloba, displaying in most 
cases a similar variability in leaf shape, lobation, and margin or lamina incision. The morphogenus Ginkgoites is used in a very technical way. Seward (1919) introduced Ginkgoites for those fossil Ginkgo-like leaves where an unambiguous generic identity with modern-day Ginkgo cannot be confirmed because of the lack of important characters from reproductive structures. Florin (1936a) extended this to include epidermal and morphological anatomical characteristics: "Fossil Ginkgo-like leaves, in which epidermal anatomy or major anatomical characters are unknown or considerably different to leaves of modernday Ginkgo biloba, are assigned to Ginkgoites" (p. 105). Watson et al. (1999) recommended, after careful reconsideration of the history of the fluctuating nomenclature of ginkgoalean leaves, a "return to the use of Ginkgoites Seward" (p. 721) for sparse and/or fragmentary vegetative material that is clearly of ginkgoalean affinity. A similar approach was deployed by Ash (2010) and Villar de Seoane et al. (2015).

Type. Ginkgoites obovatus (Nathorst) Seward; from the Rhaetian of Bjuv, Scania, Sweden.

$$
\text { Species-Ginkgoites sp. (Fig. 2A) }
$$

Material. Specimen LPP 24212 from Kvalpynten, Edgeøya, Svalbard, stored in the palaeobotanical collections of the LPP, Utrecht, Netherlands.

Additional specimens possibly belonging here. Ginkgoites sp. Kräusel 1943 (p. 76, pl. 1, figs. 9, 10); Ginkgoites sp. Kräusel 1949 (p. 38, pl. 6, figs. 2, 3; text fig. 1); Ginkgoites sp. Vasilevskaya 1983 (p. 149, pl. 5, fig. 4; pl. 6, fig. 1).

Horizon and age. Undifferentiated formation (Carnian) within the Upper Triassic-Lower Jurassic Kapp Toscana Group.

Description. The leaf under study shows a typical Ginkgotype shape and outline (fig. 2A). It is broadly fan shaped, with a distinct petiole. The petiole is $1 \mathrm{~mm}$ wide, and the preserved portion is $3 \mathrm{~mm}$ long, but the petiole appears to have been much longer. The transition from the petiole to the leaf lamina (sinus) is $110^{\circ}-120^{\circ}$; the outer margin of the lamina is straight, with almost no curvature. The lamina is deeply dissected into three orders of tongue-shaped, slender lobes; the incisions reach almost down to the leaf base. Three first-order lobes are preserved, whereof the middle one is almost completely preserved, whereas of the lateral ones only the basal portion is preserved. First-order lobes are incised until c. $50 \%-70 \%$ of their length, while second-order lobes are incised by only $25 \%-30 \%$. Thirdorder lobes are very short and terminate in acutely rounded apices. Vein density is $10-13$ veins $/ \mathrm{cm}$.

Measurements. Leaf: length: $35 \mathrm{~mm}$, preserved width: $22 \mathrm{~mm}$, estimated width: 60-65 mm; first-order lobes: length: $28 \mathrm{~mm}$, width at widest point: $10-12 \mathrm{~mm}$; second-order lobes: length: $17 \mathrm{~mm}$, width at widest point: 4-5 $\mathrm{mm}$; third-order lobes: length: 3-6 mm, width at widest point: $2-2.5 \mathrm{~mm}$; petiole: preserved length: $3 \mathrm{~mm}$, width: $1 \mathrm{~mm}$.

Remarks. We assigned the leaf to the fossil morphogenus Ginkgoites because of its clearly ginkgoalean affinity, based on its unmistakable morphology and shape, and because the vegetative material is sparse and fragmentary (one specimen only). We hereby follow Watson et al. (1999), Ash (2010), and Villar de Seoane et al. (2015). However, we refrain from formally introducing a new species because epidermal anatomy, which is a feature necessary to clearly identify ginkgoalean species and to separate Ginkgo from Ginkgoites, and fertile organs are unavailable so far. The discovery of additional material might allow description of a new species. A morphometrical analysis, such as that deployed by Bauer et al. (2013) to distinguish between ginkgoalean species when only vegetative impression material is available, was not warranted here because of a limited sample size (one specimen only). In addition, Bauer et al. (2013) were not able to convincingly demonstrate that serious discrimination between species is possible if the sample size is small to moderate. Other attempts to apply morphometric analyses to vegetative foliage (e.g., Burnham 1986; Denk and Dillhoff 2005) were unsuccessful as well and demonstrated the limits of the approach. Substantial, long-standing experience shows that personal visual perception when allocating specimens to different taxa is, instead, more reliable than any mathematical formula or statistical analysis (T. Denk, personal communication, July 9, 2015; see, e.g., Denk and Dillhoff 2005).

One other fan-shaped Ginkgo-type leaf has been reported from the Triassic of Svalbard by Vasilevskaya (1983), namely, Ginkgoites sp. This single specimen was found at Kollerfjellet on Hopen, and Vasilevskaya (1983) apparently was able to isolate cuticle from it. The paper by Vasilevskaya (1983) contains no description of epidermal anatomy, despite figures of apparently well-preserved upper and lower cuticle and a close-up of one stoma. However, the figures in Vasilevskaya (1983, pl. 5, fig. 4; pl. 6, fig. 1) are of too poor a quality to recognize precise details. Whether Vasilevskaya's specimen is conspecific with the one presented here remains equivocal until new material with preserved organic remains (including epidermal anatomy) is discovered. The substantial agreement in the composition of the Svalbard and Lunz/Neuewelt floras (Launis et al. 2014; Pott $2014 b$ ) might be cited in support of regarding the small leaves reported from Lunz, Austria, as Ginkgoites sp. by Kräusel $(1943,1949)$ to be conspecific with the leaves from Svalbard. Kräusel $(1943,1949)$ interpreted them as spathaceous bracts of Ginkgoites lunzensis (Stur) Florin, but we think this is questionable, given that modern Ginkgo has such bracts only around emerging short shoots bearing reproductive organs.

Comparison. Most ginkgophytes from Upper Triassic (Carnian) deposits of the Northern Hemisphere have tongue-shaped or lanceolate entire leaves that were arranged in bundles on short shoots (Kräusel 1943; Vasilevskaya 1972, 1983; Dobruskina 1994; Pott and Krings 2010; Pott 2014b) and usually are assigned to Arberophyllum or Desmiophyllum Lesquereux. Therefore, only a few ginkgophyte leaves from the Carnian can be compared with Ginkgoites sp.

Europe. From the Carnian floras of Lunz and Neuewelt, Basel, Switzerland, which are largely identical to the Svalbard flora (Vasilevskaya 1972; Pott and Krings 2010; Launis et al. 2014; Pott 2014b; Pott and Launis 2015), one species of Ginkgoites has been reported (Ginkgoites lunzensis; Kräusel 1943; Pott and Krings 2010). Leaves of Ginkgoites lunzensis are 2.5-3 times larger than leaves of Ginkgoites sp. from Svalbard, and in our opinion, this is beyond the specific variability of the two species. Therefore, we do not regard the two taxa as conspecific (Kräusel 1943; Vasilevskaya 1972). Other Ginkgoites species are not known to us from any Late Triassic flora of Europe. Carnian sediments in Greenland lack fossil plant remains (K. Raunsgaard Pedersen, personal communication, March 2012). Sphenobaiera furcata (Heer) Florin from Neuewelt 

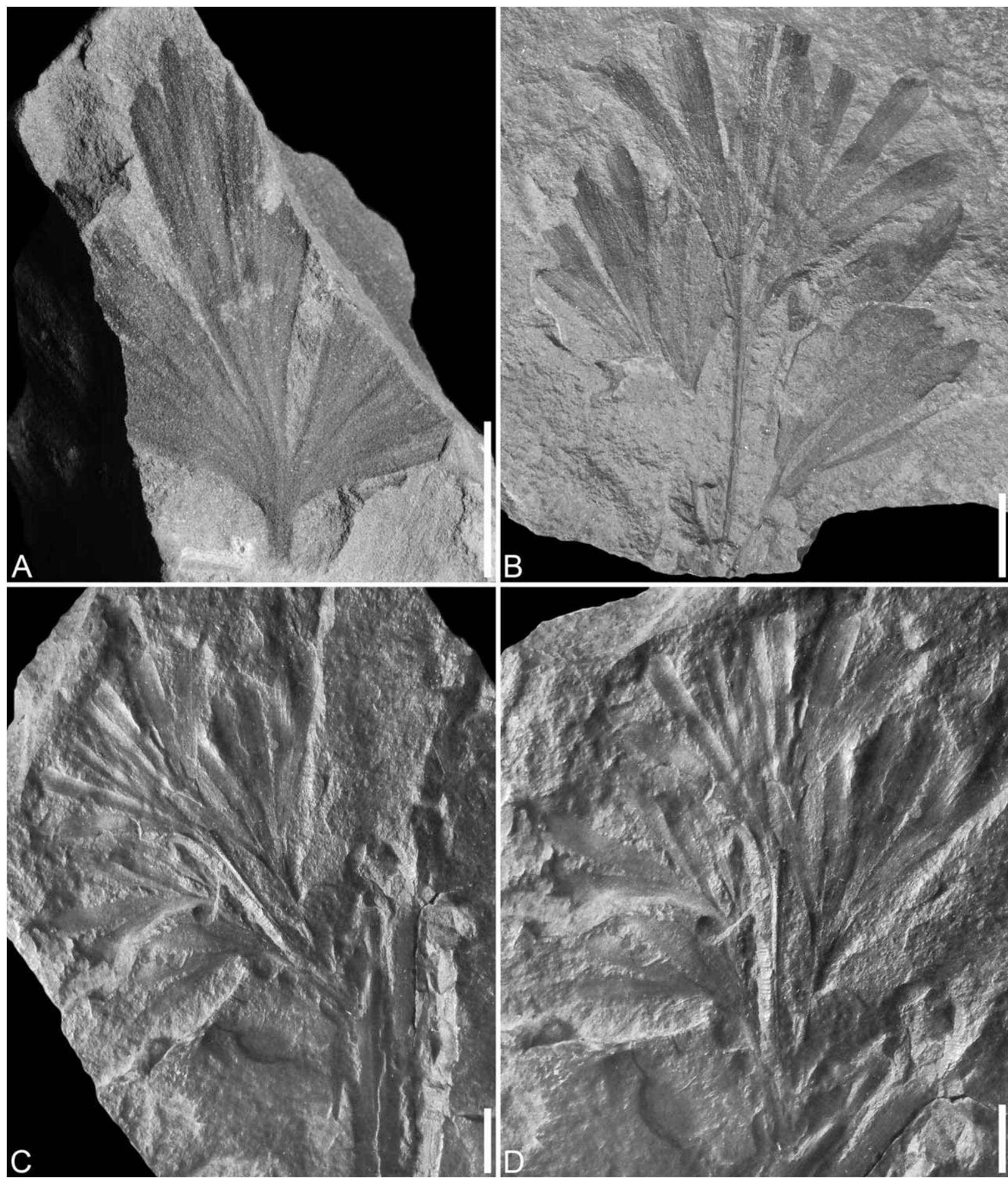

Fig. 2 New ginkgophyte species from Svalbard. A, Ginkgoites sp. from Kvalpynten (site 9 in fig. 1), LPP 24212. B-D, Baiera aquilonia sp. nov. from Bohemanneset (13). B, Four leaves arranged in a cluster (counterpart of C), G.333.1922. C, Four leaves arranged in a cluster, attached to a prominent axis, holotype, LPP 353. D, Detail of $C$, photographed under a different light angle. Scale bars $=10 \mathrm{~mm}$.

(Kräusel 1943; Vasilevskaya 1983) is characterized by very slender leaves that are regularly bifurcate, but the lamina is restricted to 2-3-mm-wide leaf segments.

North America. The Carnian floras of North America outside Greenland (mainly the Newark Supergroup [North Caro- lina] and the Heiberg [Ellsemere Island, Canada] and Santa Clara [Mexico] Formations) are largely free of ginkgophytes. Ash $(1980,1989,2010)$ lists one species of Baiera Braun, two species each of Sphenobaiera and Ginkgoites, and one species of Ginkgo, with c. 40 specimens altogether. Ginkgoites milfor- 
densis Bock differs from the Svalbard leaf by its entire, undivided first-order lobes and Ginkgoites watsoniae Ash by its much thinner and regularly incised leaf segments (Ash 2010). In contrast, Ginkgo sibirica Heer from the Heiberg Formation of Ellesmere Island in Arctic Canada is very similar to the Svalbard leaf in the shape of the leaf segments and overall outline, but the leaf is much broader, with a basal angle of more than $180^{\circ}$ (Ash and Basinger 1991; Ash 2010). The enigmatic taxon Eoginkgoites Bock, originally described as a ginkgophyte, was later identified as a bennettite (Ash 1976, 2010; Axsmith et al. 1995; Pott and Axsmith 2015).

Asia. According to Dobruskina (1994), Carnian ginkgophytes have been reported from a number of areas in Eurasia. In all covered areas, they were relatively rare in abundance and very locally restricted in distribution. Most Carnian ginkgophytes were members of the more strap-shaped taxa Arberophyllum, Desmiophyllum, and Sphenobaiera, whereas fan-shaped ginkgoalean leaves are rare. Leaves comparable to Ginkgoites sp. from Svalbard are known only from the southern Ural region (Chelyabinsk Basin: Ginkgoites donetzianus Prynada [Kiritchkova 1969]), the Burluk River Basin in western Kazakhstan (Ginkgoites burlukensis Orlovskaya [Orlovskaya 1979]), the Carnian of Madygen (Ginkgoites taeniatus [Braun] Harris [Sixtel 1962; Dobruskina 1994]), the Huang He River Basin in northern China (Ginkgoites chowii Sze, Ginkgoites magnifolius [Fontaine] Du Toit [Sze 1956]), the Chinese provinces Shanxi, Gansu, and Ningxia (Ginkgoites cf. digitatus, Ginkgoites magnifolius [Huang and Zhou 1980]), and the Yangcaogou Formation of western Liaoning (Ginkgoites papilionaceus Zhou [Zhou 1981]). In southern Primorye, fan-shaped ginkgophytes occur only in Norian deposits (Shorokhova 1997). All these species are easily discriminated from Ginkgoites sp. from Svalbard. Ginkgoites donetzianus is similar in size to Ginkgoites sp. from Svalbard, but the laminae have more numerous and deeper incisions, the lobes appear wider, and the lobe apices are bluntly truncate instead of acutely rounded, as in Ginkgoites sp. from Svalbard (Kiritchkova 1969). Ginkgoites burlukensis shows fan-shaped leaves that are dissected into very slender leaf segments appearing comb shaped (Orlovskaya 1979). Ginkgoites taeniatus is also of similar size range, with a similar appearance, but the lobes appear much more fan shaped in Ginkgoites sp. from Svalbard, whereas they are almost parallel sided in Ginkgoites taeniatus. Ginkgoites taeniatus is known in Europe exclusively from Rhaetian-Early Liassic deposits, including those in Greenland and Germany (Gothan 1914; Harris 1935). The records from Scania are questionable (Harris 1935; Lundblad 1959). Therefore, it is questionable whether the specimens from the Carnian of Madygen are correctly identified. Ginkgoites chowii as well is similar in terms of size range, but the lamina is less to almost not incised, with an outer margin appearing dentate (Sze 1956), whereas Ginkgoites magnifolius has very robust leaves with generally four broad tongue-shaped lobes that are bluntly rounded apically, incised to only one-third of the lamina (Sze 1956). Ginkgoites papilionaceous is a very tiny leaf with a deeply incised lamina of only $10 \mathrm{~mm} \times 14 \mathrm{~mm}$. Its lobe apices are widely rounded to almost truncate.

Rhaetian floras from adjacent areas. The Rhaetian sediments from Jameson Land, East Greenland, yield a considerable number of leaf types assigned to Ginkgoites (i.e., 6 species) that all occur in moderate abundance. All of these are well known, including details of their epidermal anatomy (Harris 1935). Two species that more closely resemble Ginkgoites sp. from Svalbard are Ginkgoites taeniatus and Ginkgoites acosmius Harris, which are similar in shape, division, and outline of lamina and venation. The overall shape of Ginkgoites taeniatus leaves appears rather disheveled compared to the straight lobes of the Svalbard specimen; it also has slenderer lamina segments. The latter is, however, known from one specimen only, and consequently this fact cannot be considered a discriminating character so far. The leaf segment apices of Ginkgoites acosmius are irregularly notched, which is different from the few preserved but regularly acutely rounded apices in Ginkgoites sp., but the overall shape of Ginkgoites acosmius is similar to that of Ginkgoites sp. All other leaves from Jameson Land are easily discriminated from Ginkgoites sp. by their differing lamina appearance and lobe apices (Harris 1935). From the Rhaetian of Scania, leaf types similar if not identical to those of the Greenland fossils, but also new ones (i.e., Ginkgoites troedsonii Lundblad), have been described (e.g., Nathorst 1878-1886; Florin 1936a; Lundblad 1959). Ginkgoites troedsonii approaches Ginkgoites sp., but is different in its less fan-shaped but more club-shaped lobes, and Ginkgoites taeniatus has not been recognized from Scania so far (Lundblad 1959). Recently, a very diverse flora has been collected from Upper Triassic deposits (most probably Norian) from Ellesmere Island, which, after initial observations (C. Pott, personal observation, February 2014), is characterized by a relatively high percentage of fan-shaped ginkgophytes in terms of numbers of species and individual specimens. This flora is awaiting thorough study by C. Pott and colleagues.

Abundanceldistribution. Ginkgoites sp. on Svalbard has been found only at Kvalpynten.

$$
\text { Genus-Baiera Braun }
$$

The genus Baiera is characterized by fan-shaped leaves with a lamina that is highly dissected and deeply incised into slender, almost parallel-sided segments that bifurcate apically with an incision usually reaching down to $80 \%-90 \%$ of the subordinate lobes. Baiera leaves are distinguished from Sphenobaiera leaves by the presence of a distinct petiole (Florin 1936a). The cuticle (when known) is well developed (thick); leaves are usually amphistomatic, with haplocheilic stomata scattered or in short longitudinal files between veins (Florin 1936b; Harris and Millington 1974). Baiera leaves are distinguished from Ginkgoites leaves by their slender and linear leaf segments (lobes), usually characterized by $2-4$ veins.

Type. Baiera muensteriana (Presl) Heer; from the Rhaetian of Bamberg, Germany.

$$
\begin{gathered}
\text { Species-Baiera aquilonia C.Pott, Burgh and } \\
\text { Van Konijnenb. sp. nov. (Fig. 2B-2D) }
\end{gathered}
$$

Diagnosis. Sterile foliage arranged in clusters; leaf distinctly petiolate, with long petiole; lamina fan shaped, deeply dissected into slender, almost parallel-sided segments of uniform width; lamina dissected into three orders of lobes; first-order incisions reach down to leaf base, second-order lobes are deeply incised (up to $80 \%$ of their length), and third-order lobe apices bluntly rounded; 14-16 veins/cm.

Etymology. The Latin aquilonius means "northerly."

Type specimen. Specimen LPP 353 from Bohemanneset, Spitsbergen, Svalbard, stored in the palaeobotanical collections 
of the LPP, Utrecht, Netherlands (fig. 2C, 2D). The specimen G.333.1922 from the collection of the Utrecht University $\mathrm{Mu}-$ seum (but presently stored at the LPP) is the counterpart of (the upper part) of the type specimen (fig. 2B).

Type horizon and age. Helvetiafjellet Formation (BarremianAptian) within the Jurassic-Cretaceous Adventdalen Group.

Description. The type specimen represents a 12-13-mmwide axis bearing a cluster of four leaves that show a typical Baiera-type shape and outline (fig. 2B-2D). The leaves are narrowly fan shaped, with a distinct and long petiole that is up to $1 \mathrm{~mm}$ wide and up to $34 \mathrm{~mm}$ long. The petiole shows a longitudinal depression on its presumed adaxial side; the petiole appears to be keeled (fig. 2B). Two other leaves have shorter petioles, 17 and $20 \mathrm{~mm}$ long. Of the fourth, the petiole is not fully visible but is between 20 and $24 \mathrm{~mm}$ long. The length of the lamina could be measured in only one leaf, where it is $43 \mathrm{~mm}$. The smooth transition from the petiole to the leaf lamina (sinus) is $130^{\circ}-140^{\circ}$; the outer margin of the lamina is straight, with no curvature. The basal angle of the lamina is less than $60^{\circ}-90^{\circ}$. The lamina is deeply dissected symmetrically into three orders of slender, almost parallel-sided lobes, which insignificantly widen toward their apices; the incisions reach almost down to the lamina base. Two first-order lobes are each deeply divided into two lobes, each of which is again deeply incised once. Incision of first-order lobes is approximately $90 \%$ of their length, while second-order lobes are incised by c. $75 \%-80 \%$. Thirdorder lobes terminate in acutely rounded apices. Venation density is $14-16$ veins $/ \mathrm{cm}$. The four leaves are arranged in a cluster attached in one point to the axis (fig. 2C,2D). A tiny short shoot might be present but is not unequivocally recognizable. The counterpart shows only the upper portion of the specimen, depicting only the four leaves (fig. $2 B$ ).

Measurements. Leaf: length: 39-69 mm, width: up to $39 \mathrm{~mm}$; first-order lobe length: $26-34 \mathrm{~mm}$; second-order lobe length: 18-28 mm; third-order lobes: length: $12-16 \mathrm{~mm}$, width at widest point: $3.4-4.2 \mathrm{~mm}$; petiole: preserved length: $13-31 \mathrm{~mm}$, width: $1 \mathrm{~mm}$.

Remarks. The leaves described here are definitively Baieratype leaves, on the basis of their distinctive morphology and shape. They are distinguished from any Sphenobaiera leaf by their long and distinct petiole and from any Ginkgo or Ginkgoites leaf by their slender, almost parallel-sided segments and deeply incised lamina. Epidermal anatomy remains unknown because of a lack of preserved cuticle. We have assigned the foliage to a new species because, after careful consideration of the species from Lower Cretaceous deposits of the Northern Hemisphere of which we are aware (see below), we regard Baiera aquilonia as different from all of them. No Baiera leaf has so far been reported from the Lower Cretaceous of Svalbard. Lower Cretaceous ginkgophytes from Svalbard instead include Sphenobaiera-, Ginkgoites-, and Pseudotorellia-type leaves, all of which also occur at Bohemanneset (Vasilevskaya 1980).

Comparison. Confusion remains in several species assigned to Baiera or Ginkgoites because of a high number of intermediate forms (Florin 1936a; Zhou 2009; Ash 2010). We here compare species by the original assignments of Florin (1936a) without discussing whether their assignment is correct.

A morphometric analysis, such as that performed by Bauer et al. (2013), would probably not help to resolve species delimitations for the material described here because the sample size is too small. The analysis deployed by Bauer et al. (2013) clearly illustrates the difficulties in delimiting ginkgoalean species on the basis of macromorphology if a limited number of specimens are available. After in-depth consideration of the paper by Bauer et al. (2013), we see no clear separation between the recognized species in that study ("completely different macromorphometric values" are, e.g., rather continuous and in cases overlapping; Bauer et al. 2013, p. 549). The authors were not able to convincingly demonstrate that unambiguous discrimination between species is possible. But they emphasize that characteristics such as leaf width and length and their ratio, basal angle, leaf segment shape, width, and length are useful to discriminate between species.

Baiera arctica Heer (Heer 1874a), from the Cretaceous of Ekkorfat, West Greenland, has shorter and more tongue-shaped leaf segments, and its lamina is much wider than long, compared to the much longer than wide lamina in Baiera aquilonia. Baiera concinna (Heer) Kawasaki and Baiera abnertii Kryshtofovich, from the Jurassic-Cretaceous of eastern Siberia, have much narrower segments (Heer 1876b; Kryshtofovich and Prynada 1932). Baiera (or Ginkgoites) sibirica has a basal angle of more than $180^{\circ}$ (Heer 1876b; Ash 2010), whereas that in Baiera aquilonia is less than $90^{\circ}$. Also, the material of Baiera cf. sibirica from the Middle Jurassic of Yorkshire, United Kingdom, is more like the Siberian specimens (Harris and Millington 1974), which, in addition, appear to be exclusively Jurassic. Leaf segment apices of Baiera lepida Heer are much more acute (Heer 1876b). Baiera aquilonia, instead, strongly resembles two other species from the middle Jurassic of eastern Asia: Ginkgoites irdalicus Nosova and Kiritchkova and Ginkgoites kelendensis Nosova et Kiritchkova, from the Lower Jurassic of western Kazakhstan (Kiritchkova and Nosova 2012). They are similar in their deeply dissected leaf laminae and long petioles, but they are Early Jurassic species. We are aware of very few species from Lower Cretaceous deposits of the Northern Hemisphere that are comparable with Baiera aquilonia. Baiera manchurica Yabe and Ôishi, from the Lower Cretaceous of Mongolia (Krassilov 1972, 1982), agrees very well in terms of measurements, lamina shape, and incision but has a less dense venation, and its leaves are generally larger than those of Baiera aquilonia. Most other petiolate ginkgoalean leaves from Lower Cretaceous floras with a comparable lamina appearance, including Ginkgoites pluripartitus (Schimper) Heer, Ginkgoites digitatus (Brongniart) Heer, and the Baiera sp. of Kostina and Herman (2013), among others, are all more similar to Ginkgoites- or Ginkgo-type leaves in having leaf segments much wider and more tongue or fan shaped than the parallel-sided ones of Baiera aquilonia.

Abundanceldistribution. Baiera aquilonia has been found on Svalbard exclusively at Bohemanneset so far.

\section{The Era of Ginkgophytes on Svalbard}

Different opinions exist on the delimitation of Ginkgoales. A good overview of Ginkgoales sensu strictu is given by Zhou (2009), where the author reviewed the records of the past decades and associated foliage and reproductive structures. We here concentrate on leaf genera assigned to Ginkgoales in the sense of Zhou (2009). The better defined among these include Arberophyllum (EGlossophyllum Kräusel in Zhou [2009]), Baiera, Eretmophyllum Thomas, Ginkgo, Ginkgodium Yokoyama, Ginkgoites, Pseudotorellia, and Sphenobaiera (Zhou 1997, 2009), most of which are not easily distinguished from one another be- 
cause of intermediate forms; cuticle characters are also not useful (Zhou 2009). The other mentioned genera are based on unsatisfactory material or are poorly defined (Zhou 1997); among these are Kalantarium Dobruskina and Torellia Heer. Desmiophyllum was not mentioned by Zhou (2009), as its current affinity is unresolved. In Taylor et al. (2009), it is mentioned under Iraniales, gnetophytes, and Podocarpaceae, suggesting that a ginkgoalean affinity is no longer assumed.

Plant fossil localities used in the following descriptions are taken from Pott $(2014 b)$ and work associated with the ongoing study of plant fossils from Svalbard by C. Pott. All named localities are depicted in fig. 1 ; the names follow the approved place names of the Norsk Polarinstitutt (NPI 2015b; http:// stadnamn.npolar.no).

\section{Triassic (Carnian, 237-228 Ma)}

During the Carnian, most ginkgophytes were characterized by tongue-shaped, entire-margined leaves that were arranged in tufts on short shoots or convolutedly on branching axes. Among these are Arberophyllum and Desmiophyllum, the two most widespread genera, the latter with uncertain affinity (placed variably in ginkgophytes, gnetophytes, czekanowskialeans, or podocarps; e.g., Axsmith et al. 1998; Taylor et al. 2009). From Svalbard, two species of Arberophyllum could be identified (Pott $2014 b$ ), which were fairly widespread all over Svalbard.

Arberophyllum Doweld. Arberophyllum forms an isolated taxon that differs in various morphological traits from other members of the Mesozoic ginkgophytes (Tralau 1968; Dobruskina 1998; Pott et al. 2007). The most characteristic features of Arberophyllum are the strap-shaped leaf and the absence of a petiole. The generic name is a substitute for Glossophyllum (Kräusel 1943), which is preoccupied by a genus of extant mosses (Doweld 2000; Pott 2014b).

Arberophyllum leaves are slender, lanceolate, and without a petiole. They are characterized by parallel venation; veins bifurcate basally several times to support the lamina in its whole width. Their appearance is rather robust and leathery, and the leaves are arranged either in clusters on short shoots or alternating along robust axes. Separation of Arberophyllum and Desmiophyllum foliage is almost impossible, given the weak characters differentiating these very variable but similar-appearing foliage types. If epidermal details are available, the leaves may be distinguished by the shape of the stomata, which are elongate in Desmiophyllum and circular in Arberophyllum (Florin 1936b; Kräusel 1943; Pott et al. 2007). However, this character, given by Florin (1936b), appears to be very inconsistent even in Florin's (1936b) material and hence unreliable. For macromorphological differentiation, the number of veins in the middle (i.e., broadest) portion of the leaves may indicate whether a leaf is better placed in Arberophyllum (less than 20 veins $/ \mathrm{cm}$ ) or in Desmiophyllum (more than 20 veins/cm). Under this strategy, all the Svalbard leaves are assigned to Arberophyllum, but thorough reinvestigation would be required to reliably place the specimens into either genus. Arrangement of the leaves on the axes may be helpful in the allocation of the leaves to either genus, but for this, leaves in organic connection to axes are required. The ribbon-shaped leaves of Desmiophyllum, with closely spaced, parallel veins, were borne in opposite pairs (Lesquereux 1880; Taylor et al. 2009), while Arberophyllum leaves seem to have been clustered on short shoots or convolutely (or alternately) inserted to the axes (Pott 2014b).

When cuticle is preserved, it is revealed that Arberophyllum leaves show a thick and leathery appearance and are amphistomatic (Pott et al. 2007). On the abaxial side, stomatiferous costal and nonstomatiferous intercostal fields are well defined. Stomata are distributed regularly in the costal fields; stomatal pores are randomly oriented. Epidermal cells are isodiametric, polygonal to rectangular, and arranged in longitudinal rows. The individual stomatal complexes on the adaxial and abaxial sides are separated from one another by one to several ordinary epidermal cells and are usually interconnected by idiocuticular striae. The guard cells of the round stomatal complexes are sunken and possess prominent circumporal thickenings; subsidiary cells are regularly shaped and sized. A distinct and solid papilla extends from each subsidiary cell and overarches the pit mouth (Kräusel 1943; Pott et al. 2007). Pott et al. (2007) could reveal a well-developed microrelief on the leaf surface, consisting of elevated striae and depressions in Arberophyllum florinii (Kräusel) Doweld from the Carnian of Lunz. SEM revealed that the striae are composed exclusively of cuticle material and hence represent idiocuticular structures. The striae are primarily oriented in a longitudinal direction (parallel to the lateral leaf margins) and thus form a very regular pattern. They have been interpreted to enhance water repellence of the leaves in an environment characterized by increased salinity or the presence of dust transported by sustained winds (Pott et al. 2007).

Two species of Arberophyllum have been identified on Svalbard and have recently been described in full detail by Pott (2014b), namely, Arberophyllum substrictum Pott (fig. 3A, $3 B$ ) and Arberophyllum spetsbergensis (Vasilevskaya) Doweld (fig. 3C, 3D; see Pott 2014b for details). Leaves of Arberophyllum spetsbergensis and Arberophyllum substrictum are very similar to each other; Arberophyllum spetsbergensis leaves are distinguished from those of Arberophyllum substrictum by their shorter and broader lamina, with more prominently tapered bases and apices, and by their clustered arrangement on short shoots, in contrast to the supposed convolute (or alternate) arrangement of the leaves in Arberophyllum substrictum (Pott 2014b). Arberophyllum spetsbergensis occurs widely distributed in the Carnian sediments at Fleur de Lyshamna, Hyrnefjellet, Wimanfjellet, Teistberget, Schweinfurthberget, and Kapp Lee and at Kollerjellet and Gåsskaret on Hopen, whereas Arberophyllum substrictum is widely distributed at Bertilryggen, Midterhukfjellet, Fleur de Lyshamna, Wimanfjellet, Agardhbukta, Teistberget, Kapp Lee, and Kvalpynten and at Gåsskaret on Hopen (Launis et al. 2014; Pott 2014b).

Ginkgoites Seward. Vasilevskaya (1983) reported one Ginkgoites-type leaf with preserved cuticle as Ginkgoites sp. from Kollerfjellet on Hopen. Despite its fairly good preservation and the information yielded on epidermal anatomy, Vasilevskaya (1983) refrained from providing a detailed description of the specimen, despite providing figures of the cuticles. The latter, however, are too poorly reproduced to recognize necessary details for an in-depth description. Moreover, it might be conspecific with Ginkgoites sp. described above. 

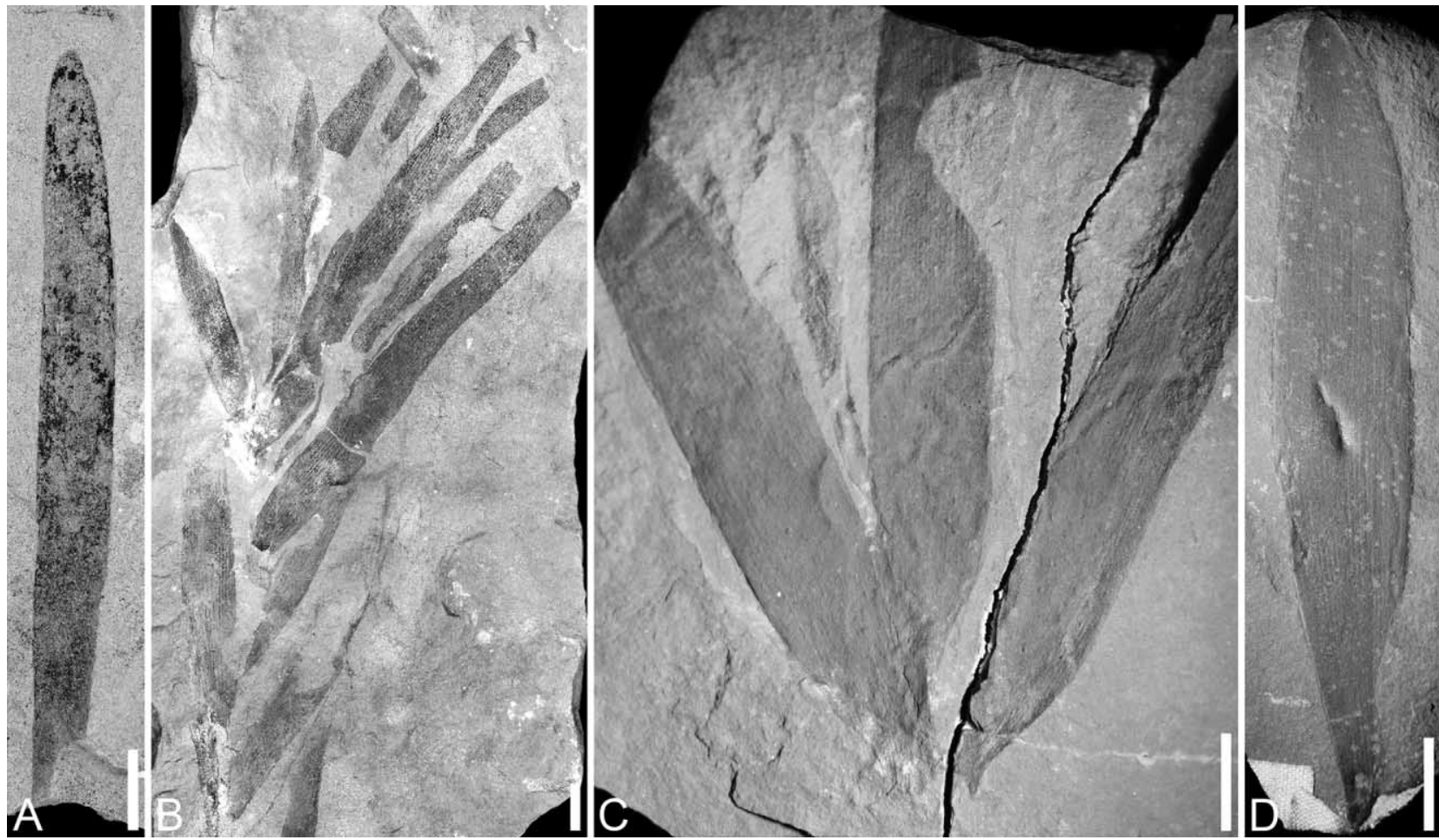

Fig. 3 Late Triassic (Carnian) ginkgophytes of Svalbard. A, Arberophyllum substrictum from Bertilryggen (site 1 in fig. 1), NRM S080255; B, Arberophyllum substrictum from Fleur de Lyshamna (8), NRM S080079; C, D, Arberophyllum spetsbergensis from Hyrnefjellet (10): C, VSEGEI 10797-95; D, VSEGEI 10797-73. Scale bars $=10 \mathrm{~mm}$.

\section{Cretaceous (Barremian-Aptian, 130-110 Ma)}

During the Early Cretaceous, the composition of the ginkgophyte flora changed and fan-shaped forms became prevailing, while the slender, strap-shaped types decreased in number and abundance. Most of the deposits had earlier been regarded as Upper Jurassic (e.g., Nathorst 1897) but are now confidently identified as Lower Cretaceous (Heer 1874a, 1877; Harland 1997).

Sphenobaiera Florin. Sphenobaiera leaves are generally characterized by a lamina that is dissected and deeply incised into slender, almost parallel-sided leaf segments that bifurcate apically with an incision usually reaching down to only $10 \%-$ $25 \%$ of the subordinate lobes. Sphenobaiera leaves are distinguished from Baiera leaves by the absence of a distinct petiole and the lower number of veins (2-4 vs. 4-6) in the leaf segments (Florin 1936a). The cuticle (when known) is well developed (thick); leaves are usually amphistomatic, with haplocheilic stomata scattered or in broad bands (Harris and Millington 1974).

Sphenobaiera longifolia (Pomel) Florin (Fig. 4A, 4B). Leaves of Sphenobaiera longifolia are characterized by as many as four dichotomies of the lamina (Harris and Millington 1974), but the material from Svalbard comprises only portions of these, usually showing only portions of the leaf base that are incised once (fig. $4 A, 4 B$ ). The distal portions with further incisions are not preserved in any of the available specimens. Leaf portions are wedge shaped, almost parallel sided, $7-12 \mathrm{~mm}$ wide, and $125 \mathrm{~mm}$ long, with a very narrow angle of branching $\left(10^{\circ}-25^{\circ}\right)$. The venation is parallel, basally dichotomizing to support the whole width of the lamina; vein density is approximately $8-11$ veins $/ \mathrm{cm}$. In some specimens, the leaf base is completely preserved, revealing the absence of a distinct petiole. The specimens fall well within the size ranges of Sphenobaiera longifolia described from Arctic and temperate Lower Cretaceous deposits elsewhere (e.g., Heer 1876a; Samylina 1956a; Harris and Millington 1974), even if epidermal details from the Svalbard specimens are unavailable. The specimens from Svalbard here allocated to Sphenobaiera longifolia have not been figured previously and were only tentatively identified by Nathorst (1897).

The assignment of the specimens from Svalbard to Sphenobaiera longifolia is still a bit problematic, as details of the epidermal anatomy are not preserved. In addition, Sphenobaiera longifolia tends to be a typical Middle-Upper Jurassic species. Harris and Millington (1974) precisely circumscribed the species, which is based mostly on epidermal details alone. Harris and Millington (1974) did not consider Nathorst's Svalbard specimens, most likely because they were not figured. The original material of Pomel (1849) and Saporta (1873) has been accepted for the species, even if the species is now mainly based on material from the Middle Jurassic of Yorkshire that yielded cuticle, while most other Jurassic specimens referring 


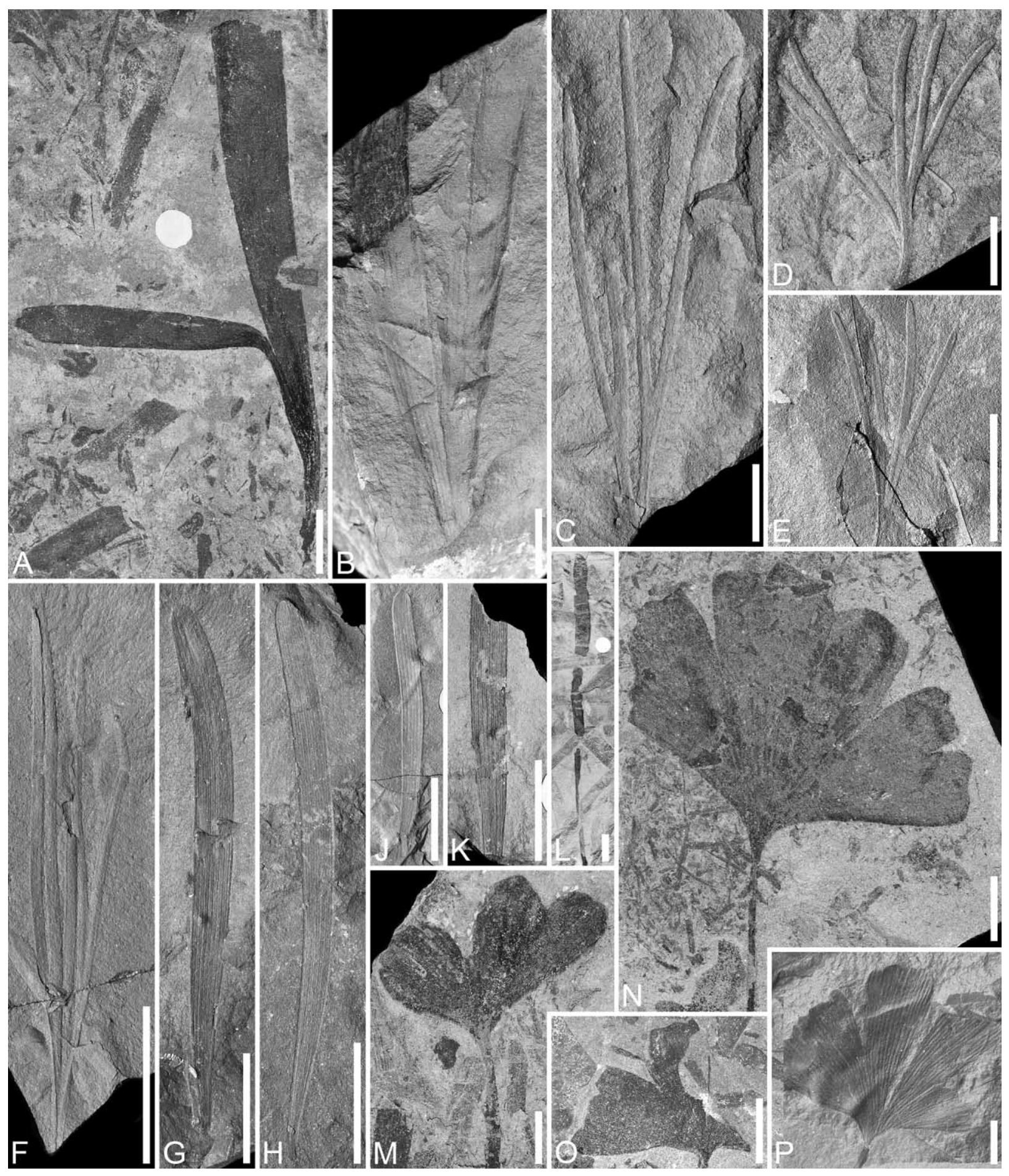

Fig. 4 Early Cretaceous (Barremian-Aptian) ginkgophytes of Svalbard. A, Sphenobaiera longifolia from Bohemanneset (site 13 in fig. 1), NRM S053302; B, Sphenobaiera longifolia from Ulladalen (17), NRM S080121; C-F, Sphenobaiera spetsbergensis from Hanaskogdalen (14): C, NRM S092587A; D, NRM S092585; E, NRM S092589; F, NRM S092590; G-K, Pseudotorellia nordenskioeldii from Hanaskogdalen (14): G, NRM S092876; H, NRM S092594B; J, NRM S092595A; K, NRM S092601A; L, Pseudotorellia sp. cf. Pseudotorellia longifolia comb. nov. from Bohemanneset (13), NRM S053342; M-P, Ginkgoites digitatus from Bohemanneset (13): M, NRM S053336; N, NRM S053329; O, NRM S053307; P: G 332.1922. Scale bars $=10 \mathrm{~mm}$. 
to Pomel's species are excluded because of the absence of epidermal details. Nevertheless, Harris and Millington (1974) accepted several specimens from the Lower Cretaceous of Siberia (Samylina 1956a), which gives this taxon a comparatively large range. This also justifies the inclusion of the specimens from Svalbard. Specimens reported recently from the Berriasian of Duingen, Germany, are almost identical to the ones from Svalbard and have been assigned to Sphenobaiera longifolia as well (Pott et al. 2014). On the basis of thorough restudy of the original specimens, we here include the specimens from the Cretaceous of Festningsodden/Kapp Starostin that were, in our view, erroneously assigned to Baiera (Sclerophyllina) cretosa (Schenk) Heer by Heer (1874a, 1876a; Nathorst 1897) and some of the specimens that were, in our view, erroneously assigned to Podozamites lanceolatus by Heer (1876a; e.g., pl. 7, fig. 4). Nathorst (1897) erroneously interpreted the leaves as split fern axes. Vasilevskaya (1980) reported Sphenobaiera ikorfatensis (Seward) Florin from the Lower Cretaceous of Svalbard, which has similar macromorphological dimensions; the author also provided details in epidermal anatomy that match those provided by Lydon et al. (2003) for the type material of Sphenobaiera ikorfatensis from the lower Cretaceous of Greenland. Lydon et al. (2003) did not consider any Svalbard specimens in their analysis, neither those reported by Heer (1876a) as Sphenobaiera longifolia nor those reported by Vasilevskaya (1980) as Sphenobaiera ikorfatensis or Sphenobaiera pulchella (Heer) Florin. A final assessment can be made only with the support of details of epidermal anatomy (see Lydon et al. 2003).

Sphenobaiera longifolia has been reported on Svalbard from Bohemanneset, Festningsodden, Langstakken, and Ulladalen, with up to 10 specimens in total; it is also present in some specimens in the collections of the NRM from unidentified localities. It is here photographically documented for the first time.

Synonymy. Dicropteris longifolia Pomel 1849 (p. 339, no illustration); Jeanpaulia longifolia Saporta 1873 (p. 464, pl. 67, fig. 1); Sphenobaiera longifolia Florin 1936a (p. 108, no illustration).

Additional records. Sclerophyllina cretosa Heer 1874 a (p. 59, pl. 13, figs. 13 , 14; pl. 17, fig. 12; p. 124, pl. 35, figs. 8-10); Baiera cretosa Heer $1876 a$ (p. 49, no illustration); Podozamites lanceolatus pro parte Heer 1876 a (p. 35, pl. 7, fig. 4a); Baiera longifolia Heer 1876 a (p. 39, p. 8, fig. 6); Baiera longifolia Heer 1876 b (p. 52, pl. 7, figs 2, 3; pls. 8, 9, figs. 1-11; pl. 10, figs. 6, 7; pl. 15, fig. 11b); cfr. Baiera longifolia Nathorst 1897 (p. 15, no illustration); Baiera (Sclerophyllina) cretosa Nathorst 1897 (p. 33, no illustration); Baiera longifolia Nathorst 1910 (p. 367, no illustration); Baiera longifolia Nathorst 1919 (p. 243, no illustration); Sphenobaiera longifolia Harris and Millington 1974 (p. 43, pl. 1, figs. 3-5; text fig. 15).

Sphenobaiera spetsbergensis (Nathorst) Florin (Fig. 4C-4F). Sphenobaiera spetsbergensis comprises very small and delicate but have thick leaves that are bifurcated into two very long first-order leaf segments (fig. 4C, 4F). These are again deeply bifurcated, with a very narrow angle of branching $\left(10^{\circ}-15^{\circ}\right.$; fig. 4D, 4E). Leaves are 25-30 $\mathrm{mm}$ long and 6-15 $\mathrm{mm}$ wide; individual segments are at maximum $1 \mathrm{~mm}$ wide. A petiole is lacking; the petiole-like portion of the lamina appearing in fig. $4 D$ is formed by the superimposition of the basal portions of the primary leaf segments. The leaves are amphistomatic, but the lamina is not differentiated in stomata-free zones and zones with stomata. The haplocheilic stomata are surrounded by 4-7 papillate subsidiary cells that create a slightly sunken stoma covered by the papillae (Nathorst 1897; Florin 1936b). We agree with Florin (1936b) in including Baiera graminea of Nathorst (1897) here.

Sphenobaiera spetsbergensis is exclusively found at Hanaskogdalen, with a moderate number of specimens $(n=15-18)$. The species is here photographically documented for the first time.

Synonymy. Baiera spetsbergensis Nathorst 1897 (p. 53, pl. 3, figs. 6-12); Baiera graminea Nathorst 1897 (p. 54, pl. 3, fig. 13); Sphenobaiera spetsbergensis Florin 1936 a (p. 39, pl. 5, figs. 5-11).

Additional records. "Problematischer Blattrest" Nathorst 1897 (p. 72, pl. 6, fig. 22); Baiera spetsbergensis Nathorst 1910 (p. 365; no illustration).

Pseudotorellia Florin. Psendotorellia was introduced by Florin (1936a) for slender, lanceolate, or tongue-shaped leaves with a leathery appearance, a roundish apex, and a short, almost invisible petiole. Leaves are entire-margined and undivided and show a moderate number of veins that emerge from repeated basal bifurcations. Leaves are hypostomatic and show a distinct separation between stomata-free zones and bands with stomata. Stomata are haplocheilic (Florin 1936a). Florin (1936a) erected the genus mainly to separate the older (Jurassic-Cretaceous) forms from the much younger Tertiary forms that are allocated to Torellia. The difference between them is cryptically recognized in the different cutinization of subsidiary and normal epidermal cells.

Lundblad (1957, 1968) and Bose and Manum (1990) translated and slightly emended Florin's diagnosis of the genus, not accepting the emendation by Watson (1969) that was done to include a Wealden species, which later turned out to be a synonym of the conifer Abietites linkii (Römer) Dunker (Watson and Harrison 1998). Bose and Manum (1990) discussed the genus circumscription and also its position, treating it as ginkgophyte. From bulk material, Bose and Manum (1990) described two additional species from Bohemanneset.

The assignment of Pseudotorellia to the Ginkgoales or ginkgophytes has recently been challenged (Watson and Harrison 1998), and its taxonomic position is currently debated (Kiritchkova and Nosova 2009). A consensus has not been reached yet, and it remains unclear whether Pseudotorellia is a ginkgophyte or a conifer similar to broad-leaved, multiveined conifers of the Araucariaceae. According to Kiritchkova and Nosova (2009), at least some of the species assigned to Psendotorellia are definitely ginkgophytic, whereas some others might be coniferophytic, according to Watson and Harrison (1998). The latter paper, however, was not considered by Kiritchkova and Nosova (2009), who accepted the Svalbard species as ginkgophyte. We here regard the specimens from the Lower Cretaceous of Svalbard as ginkgophytes on the basis of Florin's (1936a) detailed description of their macromorphology and epidermal anatomy, which was also the reason Kiritchkova and Nosova (2009, p. 618) assigned them to Ginkgoales ("We believe that the vena- 
tion character and epidermal topography of the leaves correspond to the Ginkgoales members rather than to conifers. This was also stated by Harris (1935)" and resubstantiated by Harris and Millington [1974]). However, the authors did not give further notice of what those characters are. If the characters pointed out by Watson and Harrison (1998; hypostomatic, fewer veins, thick cuticles, strictly longitudinal alignment, and elongation of stomata and all ordinary epidermal cells) are considered to assign Pseudotorellia to conifers rather than to ginkgophytes, then other genera, such as Arberophyllum and Desmiophyllum, that are regarded as ginkgophytes would also have to be reconsidered as conifers rather than ginkgophytes. It has to be admitted that even Kiritchkova and Nosova (2009) do not provide strong evidence why the characters they define for Pseudotorellia justify a ginkgophyte affinity. However, strong evidence for a ginkgoalean affinity comes from Krassilov (1970, 1972), who found Pseudotorellia leaves attached to Ginkgo-like short shoots. It finally can be concluded that some species of Pseudotorellia might be ginkgophyte and others conifer and that an individual species has to be classified by the analysis of its epidermal anatomy.

Pseudotorellia nordenskioeldii (Nathorst) Florin (Fig. 4G-4K). Pseudotorellia nordenskioeldii comprises very small, slender, slightly crescent-shaped single leaves that are entire-margined and characterized by a lamina tapering toward a slender leaf base and ending apically rather abruptly in a rounded apex (fig. $4 G, 4 H$ ). Leaves are 3-4 mm wide generally, but smaller ones can reach only up to $2.5 \mathrm{~mm}$, and leaves are up to $44 \mathrm{~mm}$ long. The lamina has 6-8 parallel veins (fig. 4J, 4K) that emerge from a few basal bifurcations of the entering veins. Leaves up to $6 \mathrm{~mm}$ wide occur rarely; those can have up to 10 veins at their widest portion, which is about two-thirds of the way toward the apex (Nathorst 1897). The leaves are hypostomatic; stomata are confined to well-defined stomatal bands that are separated by very thin nonstomatiferous areas. Stomata are strictly separated by a few epidermal cells, and pores are longitudinally oriented; the epidermal cells are characterized by a central, papilla-like bulge. Hairs and idiocuticular striae are absent. The epidermal anatomy has been analyzed in detail by Florin (1936a), who assigned the species to a new genus on the basis of his analyses of the epidermal anatomy but also revealed the ginkgophyte nature of the leaves (Florin 1936a; but see discussion above).

The linear leaves with several parallel veins from the Tertiary and Cretaceous sediments of Spitsbergen were originally assigned to the genus Torellia (Heer 1870), which was later found to be preoccupied by fossil mollusks, and all leaves were then assigned to the new genus Feildenia Heer on the basis of similar leaves from Canada (Heer 1878a; Nathorst 1897). The new Pseudotorellia nordenskioeldii was, therefore, originally assigned to Feildenia by Nathorst (1897) and later transferred back to Torellia by Nathorst (1910) when he recognized that the botanical nomenclature rules permit the use of the same names for plants and animals and thus recognized the validity of Torellia (Nathorst 1919). Later, Florin (1936a) established a new genus (Pseudotorellia) for the fossils from the Lower Cretaceous of Svalbard, based on cryptic differences in the cutinization of subsidiary and normal epidermal cells, to distinguish it from Torellia, especially the Tertiary-age Torellia fossils from Svalbard.
The epithet should read nordenskioeldii and not nordenskjoeldii, as proposed by Lundblad (1968), because it honors Nils Adolf Erik Nordenskiöld (1832-1901).

Pseudotorellia nordenskioeldii is exclusively found at Hanaskogdalen, with a moderate number of specimens $(n=15-$ 16). Macrofossils are here photographically documented for the first time.

Synonymy. Feildenia nordenskiöldi Nathorst 1897 (p. 56, pl. 3, figs. 16-27); Torellia nordenskiöldi Nathorst 1910 (p. 365, no illustration); Pseudotorellia nordenskiöldii Florin $1936 a$ (p. 142, pl. 38, figs. 2-5; text fig. 17).

Additional records. Torellia nordenskiöldi Nathorst 1919 (p. 242, no illustration); Pseudotorellia nordenskjoeldii Lundblad 1968 (p. 190, no illustration).

Pseudotorellia kordylina Bose and Manum. Leaves of Pseudotorellia kordylina are much smaller than those of Pseudotorellia nordenskioeldii, only $1.0-1.3 \mathrm{~cm}$ long and 1-1.5 mm wide. The lamina appears thick and leathery. The club-shaped form of the leaves ends apically regularly rounded, and proximally, the leaves taper to a very slender leaf base. Usually five veins enter the leaf, bifurcating regularly and ending straight below the leaf apex. The cuticle is thick; the leaves are hypostomatic. Nonstomatal zones are narrower than the stomatal zones. Stomata are longitudinally oriented and monocyclic, with 4-6 subsidiary cells. Guard cells are slightly sunken, and the slit-like aperture is surrounded by cutinized ridges. For further details, see Bose and Manum (1990).

Bose and Manum (1990) included material from Padloping Island, Arctic Canada, in this species. Pseudotorellia kordylina is distinguished from Pseudotorellia nordenskioeldii by its smaller leaves and the nonsinuous anticlinal walls of the epidermal cells. Pseudotorellia kordylina is exclusively found at Bohemanneset, with a moderate number of specimens, but is known only from bulk samples so far (Bose and Manum 1990). The fossils are stored in the Natural History Museum, University of Oslo, Norway, and were not photographed for our article.

Synonymy. Pseudotorellia kordylina Bose and Manum 1990 (p. 51, pl. 6, fig. 2; text fig. 21a, 21b, 21d-21i, 21k-21o).

Pseudotorellia retusa Bose and Manum. Leaves of Pseudotorellia retusa are distinguished from those of Pseudotorellia kordylina by their wider and slightly larger lamina, which is $1.0-1.9 \mathrm{~cm}$ long and 3-5 mm wide. It appears more bluntly club shaped or obovate, and the apex is retuse, with a depression slightly off the middle. The vein numbers are similar to those of Pseudotorellia kordylina, but only 6 end slightly below the apical margin, as opposed to 5-9 in Pseudotorellia kordylina. Stomata are confined to the lower surface and are more crowded but also longitudinally oriented. Adjacent stomata still only rarely share subsidiary cells, of which commonly five surround the slightly sunken guard cells. The anticlinal cell walls of ordinary cells are straight or slightly sinuous. For further information, see Bose and Manum (1990).

Pseudotorellia retusa is exclusively found at Bohemanneset, with a moderate number of specimens, but is known only from bulk samples so far (Bose and Manum 1990). The fossils are stored in the Natural History Museum, University of Oslo, and were not photographed for our article. 
Synonymy. Pseudotorellia retusa Bose and Manum 1990 (p. 52, pl. 6, fig. 1; text figs. 21c, 21j, 22).

Psendotorellia sp. cf. Psendotorellia longifolia Vakhrameev and Doludenko (Fig. 4L). Nathorst (1897) reported a specimen from Bohemanneset that he assigned with reservation to Phoenicopsis angustifolia Heer of Heer (1876b), mainly on the basis of the width of the leaves and an assumed misinterpretation of leaf tip and leaf base by Heer (1876b). Phoenicopsis Heer, however, is characterized by a single vein that enters each leaf (Taylor et al. 2009), which is not the case in the leaf in question (fig. $4 L$ ). Here, at least four different veins enter the leaf, bifurcating basally and continuing parallel toward the apex. Therefore, an alternative placement is necessary. The most complete leaf is $11 \mathrm{~cm}$ long and $5 \mathrm{~mm}$ wide, slender, and almost parallel sided, tapering toward its base to half the width of the middle portion of the lamina. The apex is not preserved in the specimens at hand, and the epidermal anatomy of the leaves is unknown at present. From their macromorphology, the leaves fit best in Pseudotorellia, approaching those assigned to Pseudotorellia ephela Harris (Harris 1935, as Torellia ephela Harris) and Pseudotorellia longifolia Vakhrameev and Doludenko (Vakhrameev and Doludenko 1961), which also reach $8 \mathrm{~cm}$ or more in length and have a width of 3-5 mm. Epidermal anatomy is known for the two latter species but not for the specimen presented here; this anatomy would be necessary to confirm our specimen's conspecificity with Pseudotorellia longifolia from the Lower Cretaceous of the Bureya Basin (Vakhrameev and Doludenko 1961; Lundblad 1968). Bose and Manum (1990) did not consider this specimen, probably because Nathorst (1897) described it as from Middle Jurassic deposits.

Pseudotorellia sp. cf. Pseudotorellia longifolia is exclusively found at Bohemanneset, with a moderate number of specimens on one slab. Macrofossils are here photographically documented for the first time.

Records possibly belonging here. cf. Phoenicopsis angustifolia Nathorst 1897 (p. 16, pl. 1, figs. 1-3); cf. Phoenicopsis angustifolia Nathorst 1910 (p. 367, no illustration); Phoenicopsis angustifolia Nathorst 1919 (p. 244, no illustration).

Ginkgoites digitatus (Brongniart) Heer (Fig. 4M-4P). The petiolate leaves assigned to Ginkgoites digitatus are characterized by a fan-shaped lamina that is moderately incised apically (fig. 4M-4P; usually down to about two-thirds of the leaf length), with each of the resulting rather wide, wedge-shaped lobes weakly (up to $4 \mathrm{~mm}$ ) incised again. Lobes are obovate to cuneate, with their widest portion almost at the apex. Entirely preserved leaves are up to $68 \mathrm{~mm}$ wide and $49 \mathrm{~mm}$ long. The leaves are petiolate, with petioles up to $35 \mathrm{~mm}$ in length or even more. Apices appear blunt and have, as far as preserved, the appearance of a small central depression. Venation is palmate and characterized by bifurcating veins, which bifurcate only in the proximal third of the leaf and proceed to the apices. Vein density is $9-11$ veins/cm. The specimens did not show any fluorescence when exposed to ultraviolet light, and cuticle has not been extracted from the Svalbard specimens.

Pott et al. (2014) pointed out that the identification of Ginkgoites digitatus is somewhat equivocal. Ginkgoites digitatus and Ginkgoites pluripartitus, which is well known, for example, from the German Berriasian (Pott et al. 2014), are both quite variable in lamina size, outline, and incisions and thus are virtually identical (Heer 1881; Pott et al. 2014). According to Florin $(1936 b)$, they are separated securely only by characters of their epidermal anatomy, which are unknown for the specimens from Svalbard. However, when we compare all specimens available from Svalbard with those published as Ginkgoites digitatus (e.g., Heer 1876a) and Ginkgoites pluripartitus (e.g., Schimper 1874; Pott et al. 2014), the leaves are, in our view, better referred to Ginkgoites digitatus than to Ginkgoites pluripartitus, on the basis of macromorphological agreement in basal angle, lamina shape, venation, incisions, and lobe apices. In this, we follow Nathorst (1897), who reported these leaves as Ginkgoites digitatus. Nathorst (1897) included here specimens from Svalbard described as Ginkgo huttonii (Sternberg) Heer and Ginkgo integriuscula by Heer (1876a), which we agree with. According to Harris and Millington (1974), Ginkgo buttonii differs from Ginkgoites digitatus by its much lower basal angle and longer lobes and the restriction of vein dichotomies to the proximal portion of the leaves, which exclude all leaves presented here from Ginkgo buttonii despite some showing a rather low basal angle. In addition, Ginkgo huttonii seems to be an exclusively Jurassic species. The specimens reported by Vasilevskaya (1980) as Ginkgo ex gr. adiantoides, Ginkgoites ex gr. sibirica, and Ginkgo polaris from the Lower Cretaceous of Spitsbergen belong here as well.

Ginkgoites digitatus is exclusively found at Bohemanneset, with up to 15 specimens. Macrofossils are here photographically documented for the first time; most of the specimens have already been published by Heer $(1876 a)$ on plate 10 , figures 1-10.

\section{Cenozoic (Paleocene, 66-65 Ma)}

From the Cenozoic onward, only a very few ginkgophytes were surviving, and the group approaches extinction in the archipelago. The survivors include a single species of fan-shaped ginkgophytes in the lower Cenozoic with comparatively large leaves allocated to the extant genus Ginkgo (Manum 1966) and another single species with very tiny, tongue-shaped leaves allocated to the somewhat enigmatic genus Torellia from the Miocene (Heer 1870). The latter, however, is assumed to derive from the Paleocene as well, because no deposits younger than the Paleocene Firkanten Formation crop out at the designated locality. Ginkgophytes younger than the Paleocene are unknown from Svalbard, and it is assumed that members of the family did not cope with the ongoing cooling climate of the archipelago and/ or that the sudden appearance of quickly adapting angiosperm competitors drove ginkgophytes to extinction on Svalbard during the late Paleocene.

Ginkgo L. Linnæus (1771, p. 313) described the leaves of Gingko as follows:

Folia (ex praecedentis anni Gemmis tretraphyllis quatuor), alterna, petiolata, cuneata, laevia, avenia, subtus striata, extimo rotundata, biloba, erosa, obtusa. Petioli longitudine folii, basi supra pubescentes, laeves, teretes, supra plani, stricti, apice excurrentes utrinque sub 


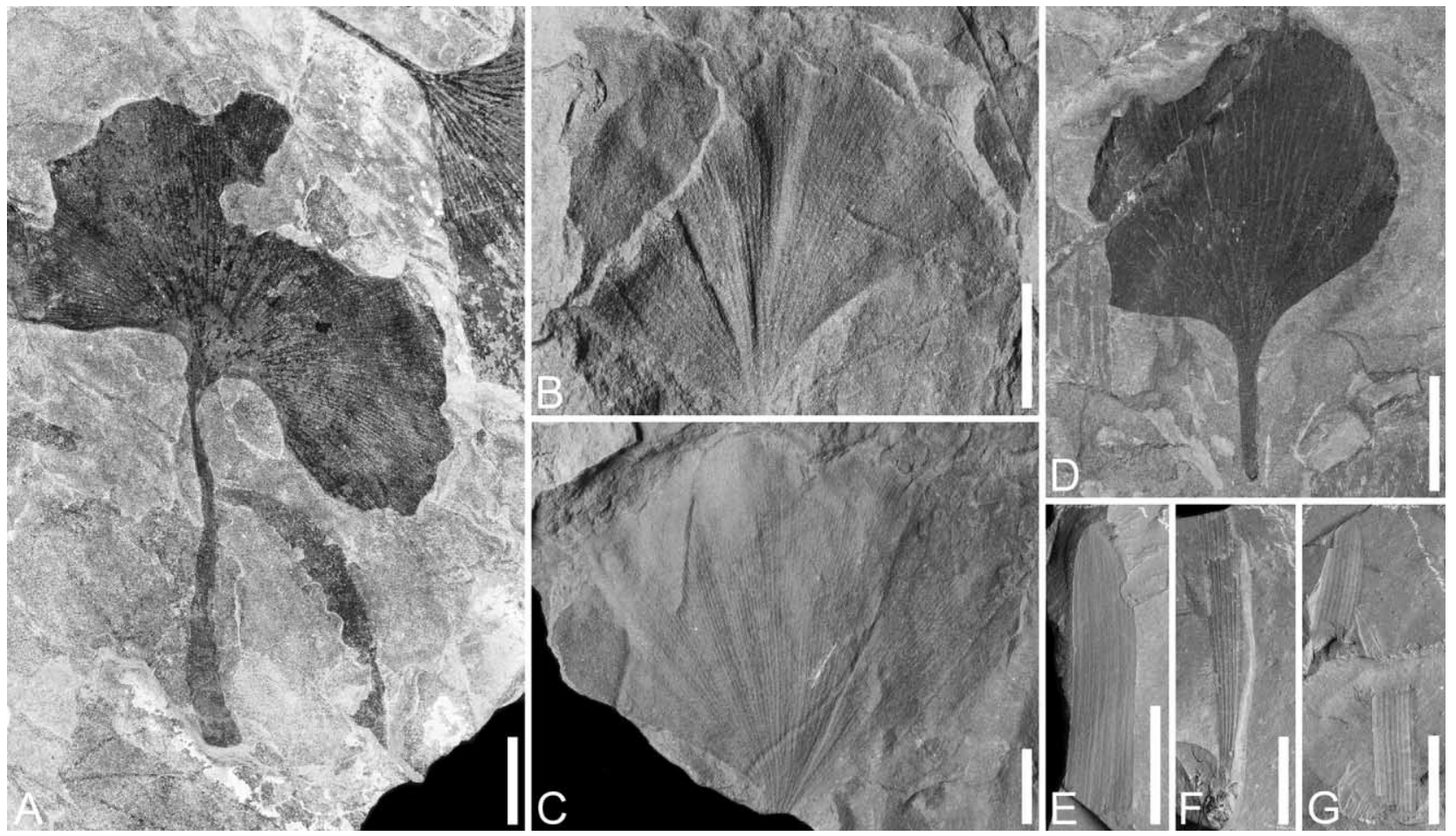

Fig. 5 Early Cenozoic (Paleocene) ginkgophytes of Svalbard. A-C, Ginkgo adiantoides from Liljevalchfjellet (site 21 in fig. 1): A, NRM S052635; B, NRM S052671; C, NRM S052674; D, Ginkgo adiantoides from Kolfjellet (20), NRM S051428; E-G, Torellia rigida from Festningsodden (15): E, NRM S050196; F, NRM S050197; G, NRM S050200A. Scale bars $=10 \mathrm{~mm}$.

folio. [Leaves (four emerging from the four-leaved buds of the previous years), alternating, petiolate, cuneate, smooth, veinless, striate on lower surface; outer margin rounded, two-lobed, irregularly toothed (erose), obtuse. Petioles as long as the leaves, basally pubescent on upper surface, smooth, terete (circular in transverse sections, tapering or narrowly cylindrical), flat on upper surface, very striate, apex projected on both sides under the leaves.]

Ginkgo adiantoides (Unger) Heer (Fig. 5A-5D). The leaves from Svalbard assigned to this species possess a 5 -cm-long and up-to-8-cm-wide fan-shaped lamina with a distinct petiole (fig. $5 A, 5 D$ ). The leaf margin is predominantly smooth, with shallow notches and gentle undulations, and rarely very deeply incised (fig. 5B-5D). The lamina is transversed by regularly dichotomizing veins with a density of about 20 veins $/ \mathrm{cm}$. Leaves are hypostomatic. Periclinal walls of adaxial epidermis cells are smooth, with no papillae or convexity; epidermal cells are elongate over veins, more or less polygonal between veins. The abaxial cuticle shows numerous round stomata between veins; epidermal cells are similar to those from the adaxial cuticle. Periclinal walls are bulged, with a distinct central papilla with thickened cuticle. Anticlinal cells in both the upper and lower epidermis are faint to slightly sinuous. Stomata are randomly oriented, very rarely sharing subsidiary cells. Each of the latter has a prominent papilla, which together cover the stomatal pit completely (see Manum 1966).

Manum (1966) introduced a new species, Ginkgo spitsbergensis, based on the leaves presented in our article, separated from other Cenozoic Ginkgo species by cryptic features in epidermal anatomy, such as the presence or absence of papillae on the lower leaf surface or the sinus amplitude of the anticlinal cell walls. However, given the variability of the epidermal anatomy (especially in the degree of the papillosity of subsidiary cells in stomata) of other Cenozoic and extant species of Ginkgo, we consider the leaves from Svalbard identical to leaves assigned to Ginkgo adiantoides from, e.g., Greenland, the Isle of Mull, or Greece (Heer 1868, 1874b, 1878c; Gardner 18831886; Florin 1936b). This is in agreement with, e.g., Denk and Velitzelos (2002), who also recognized Ginkgo spitsbergensis as Ginkgo adiantoides. The leaves from Svalbard might be regarded as a subspecies of Ginkgo adiantoides, but in our view, they do not represent a species distinctly separate from Ginkgo adiantoides. Manum (1966), when describing Ginkgo spitsbergensis, included material that was earlier identified as Ginkgo adiantoides by Nathorst (1919) and as Ginkgo sp. by SchloemerJäger (1958).

Ginkgo adiantoides leaves found together with ovulate Ginkgo organs in the Tertiary of North Dakota have recently been assigned to a new species, Ginkgo cranei Zhou, Quan and Liu. The species is differentiated from Ginkgo biloba by smaller seeds and distinct characters in seed integument cuticle (Zhou et al. 2012). According to Manum (1966), Ginkgo occurs rather sporadically in the Cenozoic of Svalbard, and only Ginkgo adiantoides occurs in the Paleocene at a restricted number of localities; it is most abundant at the foot of the Basilika Mountain and Liljevalchfjellet on Spitsbergen. The specimens of Schloemer- 
Jäger (1958) were obtained from Brøggerhalvøya close to NyÅlesund, northwestern Spitsbergen, and one specimen comes from Kolfjellet.

Synonymy. Salisburia adiantoides Unger 1845 (p. 211, no illustration); Ginkgo adiantoides Heer $1878 c$ (p. 21, pl. 2, figs. 7-10); Ginkgo spitsbergensis Manum 1966 (p. 54, pl. 1, figs. $1-5,7,8$; pl. 2, figs 1,2 , 4-6; text figs. $1 a, 1 b, 2 a$ ).

Additional records. Ginkgo adiantoides, Nathorst 1919 (p. 235, text figs. 1, 2); Ginkgo sp. indet. a, Schloemer-Jäger 1958 (p. 46, pl. 6, fig. 4; text fig. 2); Ginkgo sp. indet. b, Schloemer-Jäger 1958 (p. 46, pl. 6, fig. 5; text fig. 3); Ginkgo cf. adiantoides Manum 1963 (p. 151, text fig. 2).

Torellia Heer. Heer (1870) allocated a few slender leaves from the Cenozoic deposits of Festningsodden/Kapp Starostin to a new genus Torellia, which he assigned to taxodiaceous conifers. Florin (1936a) analyzed those Cenozoic leaves in detail and compared them with leaves assigned to Pseudotorellia nordenskioeldii by Nathorst (1897; see above) from the Barremian of Hanaskogdalen. Florin (1936a) concluded that the latter leaves are different enough in their epidermal anatomy to justify being allocated to a different genus, namely, Pseudotorellia (see above). The stomata of the Torellia leaves from the Cenozoic are in Florin's (1936a, p. 142) view "very similar to those of Ginkgo," which led him to assign both genera to ginkgophytes (Florin 1936a, p. 141: they "represent without much doubt ginkgophytes"). However, the reservation with which Florin (1936a, p. 139) allocated these genera to ginkgophytes is reflected by the fact that he calls them "not explicitly allocable." Schweitzer (1974) did not include Torellia in his "'Tertiary' conifers from Svalbard." See also the discussion of Pseudotorellia/Torellia above and the questionable assignment of these strap- or needle-like leaves to ginkgophytes.

Torellia comprises slender, lanceolate, or tongue-shaped leaves with a leathery appearance, a roundish apex, and a short, almost invisible petiole. The leaves are practically identical to those of Pseudotorellia. They are entire-margined and undivided and have a moderate number of veins that emerge from repeated basal bifurcations. Leaves are hypostomatic and show a distinct separation between stomata-free zones and bands with stomata. Stomata are haplocheilic (Florin 1936a).

Torellia rigida Heer (Fig. 5E-5G). Leaves of Torellia rigida are isolated, very tiny, lanceolate to tongue shaped, and slightly crescent shaped, with entire margins and a rounded apex (fig. 5E$5 G)$. They taper gradually toward a slender, 1-2-mm-wide base that is slightly swollen. The slender leaves are $5-8 \mathrm{~mm}$ wide but can reach $60-80 \mathrm{~mm}$ long. Eight to ten veins occur in the widest portion of the leaves, emerging from repeated bifurcations in the basal portion of the leaves. The epidermal anatomy is largely identical to that of Pseudotorellia nordenskioeldii, with the difference that epidermal cells are strongly cutinized, similarly to the subsidiary cells, while in Pseudotorellia nordenskioeldii, the subsidiary cells are more prominently and strongly cutinized and papillate than the epidermal cells. For further details, see Florin (1936a).

Torellia rigida has been reported exclusively from Festningsodden toward Grønfjorden, with fewer than 10 specimens (Heer 1870). The leaves do not occur in the two sets of unpublished plates that were to accompany the unfinished work of
Nathorst (1921) on the Tertiary flora of Svalbard (Kvaček and Manum 1997; Denk et al. 1999; T. Denk, personal communication, February 3, 2015), and thus, the macrofossils are here photographically documented for the first time.

Synonymy. Torellia rigida Heer 1870 (p. 44, pl. 6, figs. 3-12; pl. 16, fig. $1 b)$.

Additional records. Torellia rigida Nathorst 1910 (p. 386, no illustration); Torellia rigida Florin 1936 (p. 142, pl. 37, figs. 9-12; pl. 38, fig. 1; text fig. 16).

\section{Discussion}

\section{Reproductive Structures with Ginkgoalean Affinities}

To date, only sterile foliage with ginkgoalean affinities assigned to different morphogenera has been found and reported from Svalbard. Reproductive structures with ginkgoalean affinities are not known from Svalbard so far, but research, especially on the Late Triassic and Early Cretaceous flora from Svalbard, is ongoing (C. Pott, unpublished data). Because it is unlikely that a natural group within Ginkgoales, defined by one type of reproductive organs, can also be characterized by a single type of leaves (Zhou 2009), it cannot be said which type of ovulate and pollen organs is to be expected on Svalbard. Polymorphism of leafy organs is common not only among modern Ginkgo biloba but also among ginkgoalean fossils (Zhou 1997). In addition, several ginkgoalean leaf morphogenera are known to be related to more than one type of reproductive organs, and vice versa (Zhou 2009).

\section{Vegetation on Svalbard during the Different Epochs}

Svalbard has been located above $60^{\circ} \mathrm{N}$ from the Triassic onward (fig. 6), but its climate and vegetation have changed much during the archipelago's geological history. Its modern position $\left(76^{\circ}-80^{\circ} \mathrm{N}\right)$ was possibly "achieved" before the CretaceousTertiary (K-T) boundary (65 Ma; fig. 6C).

Carnian (Triassic). Extensive coal seams producing a highenergy coal substantiate that, during the Triassic, swampy vegetation dominated by ferns and bennettites prevailed, also including sphenophytes, seed ferns, and a few ginkgophytes, among others (Pott 2014b). Moreover, the Carnian vegetation was largely identical to the vegetation at the northern shore of the Tethys Ocean, located about $4500 \mathrm{~km}$, or 40 degrees of latitude, to the south (Pott 2007, 2014b; Pott et al. 2008; Pott and Krings 2010; Launis et al. 2014). Slight differences in the composition of the vegetation, however, indicate that there were climatic disparities between Svalbard in the north and the northern shore of the Tethys Ocean in the south (the Carnian floras from Lunz and Neuewelt; e.g., Kräusel 1943, 1949; Pott 2007, 2014b; Pott et al. 2008; Launis et al. 2014). During the Carnian, ginkgophytes were mostly represented by strap-shaped forms that were produced on short shoots, while fan-shaped forms were relatively rare (Dobruskina 1994; Pott et al. 2007; Pott and Krings 2010; Pott 2014b; this study). They were never abundant, but wherever Carnian floras were found, at least strapshaped ginkgophytes occurred in most cases. The latter could be an indication of rather humid environments, as the stiff, strap-shaped leaves with their surface microrelief could be interpreted as an adaptation to sustained rainfall. 

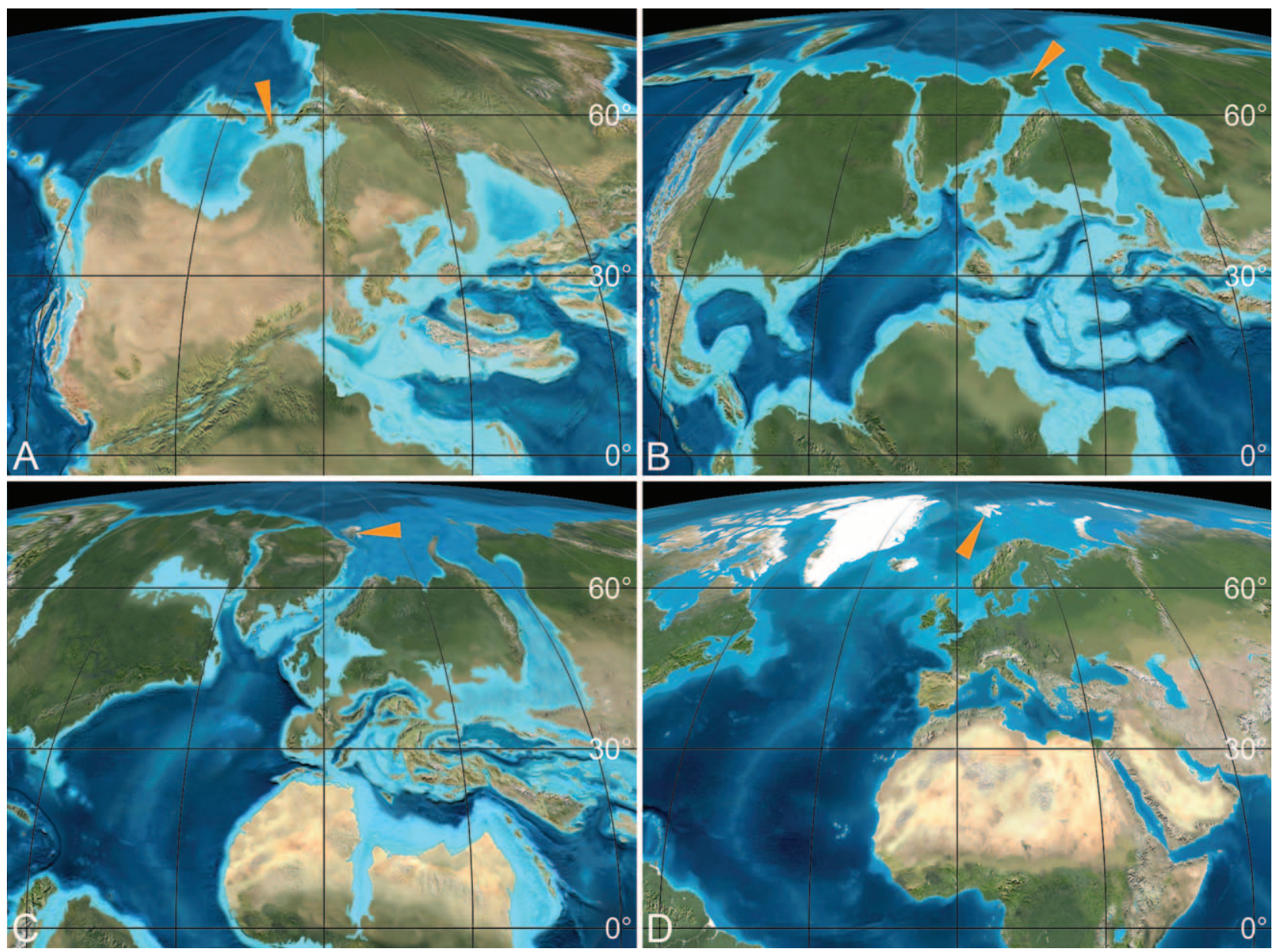

Fig. 6 Approximate palaeogeographic position of the Svalbard Archipelago (arrowheads) during the geological periods mentioned in the text: A, Late Triassic (220 Ma); B, Early Cretaceous (120 Ma); C, Early Tertiary (65 Ma); D, today (0 Ma). Palaeogeographic maps by Ron Blakey, Colorado Plateau Geosystems, Phoenix, Arizona.

Norian (Triassic). No plant fossils are known from Norian deposits in Svalbard or Greenland. The flora could have been quite similar to a Norian flora that has recently been collected from Ellesmere Island. The latter awaits thorough study, but a first glimpse revealed a high number of specimens yielding different types of mainly fan-shaped ginkgophyte leaves (C. Pott and S. Schneider, personal observation, February 2014).

Rhaetian (Triassic)-Jurassic. Plant fossils from RhaetianJurassic deposits are not known from Svalbard (see Harland 1997). Those that were previously regarded as Jurassic (e.g., Nathorst 1897) are clearly from Lower Cretaceous deposits (Heer 1874a, 1876a; Bose and Manum 1990; Harland 1997).

Early Cretaceous. The Early Cretaceous vegetation was, with regard to the prevailing plant groups, largely similar to the Middle Jurassic vegetation (see, e.g., the Yorkshire Jurassic flora; Van Konijnenburg-van Cittert and Morgans 1999) but was more variable in the number of different taxa recorded (Heer 1874a; Nathorst 1897; C. Pott, unpublished data). The cryptogam flora (sphenophytes, ferns, etc.) yielded several genera still present from the Jurassic. However, major differences can also be recognized: plant groups such as Bennettitales disappeared, whereas Nilssoniales emerged, even if low in abun- dance, but ginkgophytes and conifers continued to dominate the Svalbard ecosystem during the Cretaceous, with slightly increased diversity and abundance (Heer 1874a; Nathorst 1897; Pott et al. 2014; this study).

Cenozoic. The composition of the flora of Svalbard changed dramatically after the K-T boundary; during the Tertiary (Cenozoic, Early Paleocene-Early Oligocene), a very diverse flora was thriving on Svalbard, consisting of medium- to broad-leafed woody angiosperms and needle-leafed coniferalean gymnosperms; a few ferns, ginkgophytes, and sphenophytes were important taxa (Nathorst 1921; Kvaček and Manum 1997; Denk et al. 1999). The flora was dominated by a high diversity of mainly taxodiaceous conifers and a lower diversity of abundant (woody) angiosperms.

Whereas climate and vegetation on Svalbard were rather subtropical during the Upper Triassic-Lower Cretaceous, maybe with reduced seasonality but still with a considerably humid climate, floras from the Cenozoic reveal that the climate was strictly temperate and distinctly seasonal, became arctic during the Holocene, when glaciation on Svalbard started, and remains so today. The earlier dominating gymnosperms were gradually replaced by woody angiosperms, which in turn were 
replaced by herbaceous taxa. The modern-day flora of Svalbard includes only four woody angiosperm taxa, which are adapted to high-Arctic environments by either dwarfism or by producing subterranean main axes.

\section{Ginkgophytes in the Northern Hemisphere during the Different Epochs}

Distribution and abundance of ginkgophytes have changed considerably in the Northern Hemisphere. After about $170 \mathrm{Myr}$ of evolutionary history, during which the ginkgophytes were widespread and relatively abundant, the group underwent decline during the Cenozoic, and the lineage almost became extinct. Today, the Ginkgophyta are represented by the single extant species, the maidenhair tree Ginkgo biloba, native to central China.

Carnian (Triassic). Although not very abundant in the Carnian, ginkgophytes were widely distributed. Reproductive organs are absent from Middle Triassic floras (Zhou 2009); the Carnian marks a step of beginning radiation with floras rich in ginkgoaleans from Laurasia (Kräusel 1943; Dobruskina 1980, 1994). Ginkgophytes expanded their geographical range rapidly until the Late Triassic; strap-shaped and other fan-shaped ginkgophytes, such as Baiera and Sphenobaiera, were widely distributed in Eurasia, with a core area in China (e.g., Zhou and Wu $2006 a, 2006 b$ ). A few ginkgophytes were reported with very low abundances in the Germanic Basin, from southern Thuringia, Germany, and the Lunz and Basel environments (Kräusel 1943; Dobruskina 1994; Pott and Krings 2010). From the Ukrainian Donets region, only strap-shaped forms such as Arberophyllum and Desmiophyllum, as well as one reproductive organ (Antholithes Brongniart), are mentioned (Dobruskina 1994). For the Carnian of the Pechora Basin, Dobruskina (1994) lists several Sphenobaiera, Pseudotorellia, Ginkgoites, and Arberophyllum species as well as several species of the putative ginkgoalean genus Kalantarium. This makes this rather adjacent flora very diverse and similar to the Carnian flora of Svalbard; however, Kalantarium, for example, has not yet been reported from Svalbard. The Novaya Zemlya islands and Cap Tsvetkov, Taimyr Peninsula, yielded Desmiophyllum species, whereas no ginkgophytes are reported from Carnian deposits of Franz Josef Land (Florin 1936a, 1936b). From the southern Ural region, several Arberophyllum, Sphenobaiera, Desmiophyllum, and Kalantarium species are mentioned (Dobruskina 1994). Farther to the east, fan-shaped forms such as Baiera, Sphenobaiera, and Ginkgoites increase in abundance in the Chelyabinsk and Burluk River Basin in western Kazakhstan (Dobruskina 1994). From the Carnian of Madygen, Desmiophyllum, Ginkgoites, Sphenobaiera, and Arberophyllum have been reported, but some of the identifications are questionable (Dobruskina 1994). Farther to the east (eastern Siberia, northern Kazakhstan, Mongolia, toward the Far East), ginkgophytes are almost absent from Carnian floras (Dobruskina 1994). From northern China (Shaan-GanNing Basin, Hwang Ho River Basin), several species of Arberophyllum, Desmiophyllum, Ginkgoites, and Sphenobaiera were reported, and from Shanxi, Gansu, Ningxia, Jilin, and Liaoning, the record includes almost exclusively fan-shaped forms such as Ginkgoites, Baiera, and Sphenobaiera, with a few strap-shaped forms of Arberophyllum, Glossophyllum, and Ginkgodium (Dobruskina 1994). The Carnian of southern China contained only one record of an uncertain Desmiophyllum or Arberophyllum species. The Carnian of Japan is also rather barren of ginkgophytes; only Ginkgoites and Baiera are reported for the Yamaguti Province. The Russian southern Primorye is again well studied, and the Carnian flora comprised only fan-shaped forms such as Ginkgoites and Sphenobaiera (Dobruskina 1994). However, these and other fan-shaped ginkgophytes are derived only from Norian deposits, according to recent studies (Shorokhova 1997). North America was almost barren of ginkgophytes during the Carnian (Ash 2010).

Norian (Triassic). The Norian can be regarded as the beginning of a larger radiation and dispersal of ginkgophytes, preceding the major dispersal of ginkgophytes all over the world during the Rhaetian, at least according to synoptic reports, such as those of Vakhrameev (1991) or Dobruskina (1994), and observations by Zhou (2009) and C. Pott. It is interesting to note that very high ginkgophyte diversity in Norian floras is encountered in a region in central Asia at the border between Kazakhstan and the Russian Federation. These floras comprise several different species of ginkgophytes (including Czekanowskiales) of genera such as Baiera, Ginkgo, Ginkgoites, Ginkgodium, Czekanowskia Heer, Phoenicopsis, Kalantarium, Sphenobaiera, and Pseudotorellia, among others. Whether this can be regarded as a radiation center of diversity of ginkgophytes might be debated, but it might be considered a biodiversity hotspot of this group, and such biodiversity hotspots are regarded as centers of extensive adaptive radiations (Bibby et al. 1992). Whether this concept can be applied to fossil taxa has never been discussed (to our knowledge), but the mountains of central Asia still qualify today as one of the 34 biodiversity hotspots on Earth, and it is the only one in central Asia (CEPF 2002, 2014), connected to the fossil-rich Irano-Anatolian and Caucasian areas that also qualify as biodiversity hotspots already established in geological times. However, ginkgophytes were not restricted to this area during the Norian; they are reported from different Norian floras in central and eastern Asia. Yet their diversity was low, usually around 1-3 species of 1-2 genera, or $4 \%$ of the floral composition (e.g., Volynets et al. 2008). On the other hand, ginkgophytes have recently been found in considerable diversity in Arctic Canada (Ash 2010; C. Pott, personal observation, February 2014; C. Pott, unpublished data), challenging this assumption.

In the Southern Hemisphere, ginkgophytes were very common and abundant, with a high diversity during the Late Triassic (Anderson and Anderson 1989, 2003; Zhou 2009; Escapa et al. 2011; Villar de Seoane et al. 2015). From the CarnianNorian of the Karoo Basin, for example, Anderson and Anderson $(1989,2003)$ described 12 species of Sphenobaiera and 10 species of Ginkgoites.

Rhaetian (Triassic)-Jurassic. Ginkgophytes became a significant component of Northern Hemisphere floras from the Rhaetian onward, or at least they represented significant portions of the woody vegetation (see, e.g., Tralau 1968; Zhou 2009). It is beyond the scope of this article to give a résumé of all ginkgophytes from these periods thriving in the Northern Hemisphere, but a trend can be recognized among those welldescribed floras from, e.g., Axel Heiberg Island (Vavrek et al. 2007), Jameson Land (Harris 1935), Scania (Lundblad 1959; Tralau 1968), Germany (Schenk 1865-1867; Gothan 1914; Kirchner and Van Konijnenburg-van Cittert 1994), Poland (Barbacka et al. 2014), Hungary (Barbacka 2002), Iran and 
Afghanistan (Schweitzer and Kirchner 1995), Yorkshire (Harris and Miller 1974; Harris and Millington 1974), Scotland (Van Konijnenburg-van Cittert and Van der Burgh 1989), Norway (Manum et al. 1991), Franz Josef Land (Florin 1936a, 1936b), eastern Siberia, Amur, Aldan River, Bureya River (Heer 1876b; Prynada 1962; Samylina 1963; Vakhrameev and Doludenko 1961; Doludenko and Rasskazova 1972; Krassilov 1972; Vakhrameev 1991), China (Li 1995; Beijing: Duan 1987; Qinghai: Li et al. 1988; Liaoning/Inner Mongolia: C. Pott, P. Chen, S. Wu, S. McLoughlin, and E. M. Friis, unpublished data), Vietnam (Zeiller 1903; Akagi 1954), and Japan (Ôishi 1940; Kimura and Tsujii 1984) that fan-shaped and slit forms now prevailed over the probably more ancestral strap-shaped forms, which became a minor element after the Triassic-Jurassic boundary but still lasted until the Cenozoic. However, the affiliation of the strap-shaped forms with ginkgophytes is equivocal and has been questioned recently.

A second trend is the decline in presence and abundance from east to west. While floras from the Far East and central Russia and China include high numbers of species and specimens (e.g., Heer 1876b; Tralau 1968; Vakhrameev 1991; Zhou and Wu $2006 a$, 2006b), both decline westward through comparably moderate numbers in, e.g., central Asian and European floras, such as those of Iran and Yorkshire, to very low numbers in $\mathrm{Ca}$ nadian floras, such as those of Axel Heiberg Island or western Canada and the United States (e.g., Miller 1987; Chure et al. 2006). This is apparently independent of latitude and argues for a center of diversification (if not origin for the group) somewhere in what is China today (but see above and Zhou 1991, 1997, 2009). Strap-shaped forms such as Arberophyllum or Pseudotorellia were not considered by Zhou (1991), and the affiliation of some forms with Ginkgophyta is still debated (e.g., Phoenicopsis, Eretmophyllum, Kalantarium, Desmiophyllum, Arberophyllum, Schmeissneria, Czekanowskiales; Florin 1936a, 1936b; Harris 1951, 1976; Tralau 1968; Harris and Miller 1974; Harris and Millington 1974; Dobruskina 1994; Kirchner and Van Konijnenburg-van Cittert 1994; Pott et al. 2007; Kiritchkova and Nosova 2009, 2012).

In the Southern Hemisphere, the abundance and diversity of ginkgophytes dropped dramatically during the Jurassic to almost no record. However, in the Lower Cretaceous moderate diversity has been documented (e.g., Sharma 1974).

Early Cretaceous. The trends mentioned above continue into Lower Cretaceous deposits (Schenk 1871; Samylina 1956a, 1956b, 1963, 1974; Tralau 1968; Watson 1969; Chen et al. 1988; Vakhrameev 1991; Watson and Alvin 1996; Watson et al. 1999; Wu 1999, 2003; Austen and Batten 2011; Pott et al. 2014; Zhao et al. 2015). The Far East and Canada apparently hosted very similar floras, whereas the European floras are more similar to the subtropical flora of China (e.g., Bugdaeva 1983; Chen et al. 1988; Zheng et al. 2005; Pott et al. 2012; Zhao et al. 2015). During the Early Cretaceous, the Siberian-Canadian region (Alaska, western Canada and Montana, Svalbard, Franz-Josef-Land, and the Siberian Lena and Amur provinces) was covered with dense forests consisting of mostly Ginkgoales, Czekanowskiales, and conifers ("ancient Pinaceae"; see Heer 1876a, 1876b, 1878b; Florin 1936a; Vakhrameev 1991). The Early Cretaceous vegetation in the EuroSinian region was much more diverse, and ginkgophytes were even more common in those more temperate-to-subtropical floras (Tralau 1968; Vakhrameev 1991). A westward shift in the composition of the floras is recognized as Czekanowskiales disappeared, and a distinct decrease in number and diversity of Ginkgoales is detectable, while cycadophytes, especially Bennettitales and Nilssoniales, became much more diverse and significant in species number (Vakhrameev 1991). The Early Cretaceous flora of Svalbard (e.g., Heer 1876a) is currently under revision by C. Pott, but it fits well in the Siberian-Canadian region of Vakhrameev (1991; see update in Pott et al. 2014), as the majority of taxa are more typical of the Siberian floras (Vakhrameev 1991; C. Pott, personal observation, November 2010) including ginkgophytes.

Cenozoic. In the Cenozoic, ginkgophytes were still relatively widely distributed in the Northern Hemisphere but became significantly reduced in diversity (Tralau 1968; Zhou and Wu 2006a, 2006b; Zhou 2009). The distribution became restricted to northeastern Asia and northwestern North America toward the end of the era. Besides those from Svalbard, different Cenozoic Ginkgo species were reported from Saskatchewan (Manum 1966; McIver and Basinger 1993), Wyoming and North Dakota (Manum 1966; Zhou etal.2012), the Amur Region and the Russian Far East (Samylina 1967; Tralau 1968; Quan etal. 2010; Golovneva 2010), Japan (Ôishi 1938; Samylina and Chelebayeva 1986; Horiuchi and Kimura 1986; Uemura 1997), Sakhalin (Heer 1878c; Samylina 1967; Horiuchi and Kimura 1986), Ukraine (Samylina 1967), Greece (Velitzelos and Denk 2002), Poland (Szafer 1961), Hungary (Hably and Kvaček 1997), Germany (Florin 1936a, 1936b; Samylina 1967), Romania (Givulescu 1973), Bulgaria (Jordanov and Kitanov 1963), Italy (Unger 1850), Austria (Kovar-Eder 1988), Abkhazia (Kolakovski 1964), and Greenland (Heer 1878c), most of which have been regarded as belonging to Ginkgo adiantoides by Denk and Velitzelos (2002). However, taxonomic opinions vary (Tralau 1968; Quan et al. 2010; Zhou et al. 2012). Additional Eocene Ginkgo species are reported from British Columbia, Canada, the State of Washington, and Kamchatka (Samylina and Chelebayeva 1986; Mustoe 2002). Zhou (2009) mentioned a few Palaeogene and Neogene Ginkgo species, the foliage of most of which is morphologically largely similar to that of extant Ginkgo biloba.

The genus Ginkgo shifted in the Northern Hemisphere from high latitudes to lower latitudes from the Paleocene onward and disappeared completely from Europe by the latest Pliocene and from North America by the late Miocene (Samylina 1967; Tralau 1968; Denk and Velitzelos 2002; Zhou 2009). Other ginkgoalean genera are not known from the Paleocene and onward, except for leaves assigned to Torellia from the Paleocene of Svalbard (Heer 1870; Florin 1936a). In the Southern Hemisphere, the Cenozoic record is scarce, with a few local records that were interpreted as "hangovers" from the Late Cretaceous (e.g., Douglas 1970; Bose and Banerjee 1984; Anderson and Anderson 1989, 2003; Pole and Douglas 1999; Del Fueyo et al. 2006; Holmes and Anderson 2007; Zhou 2009; Villar de Seoane et al. 2015; S. McLoughlin, personal communication, February 27, 2015).

Decline of the ginkgophytes. Whereas most ginkgophyte taxa disappeared from the Northern Hemisphere during the Lower-Middle Cretaceous, the genus Ginkgo survived with low diversity until the Pliocene (Samylina 1967; Tralau 1968; Denk and Velitzelos 2002; Zhou 2009). The single remaining 
species, Ginkgo biloba, became confined to areas in eastern Asia, where it survives today (Shen et al. 2005; Zhou 2009). Villar de Seoane et al. (2015) summarized arguments that were used to explain the decline and disappearance of ginkgophytes from the Southern Hemisphere. Similar causes can be assumed for the Northern Hemisphere, including Svalbard. Cooling conditions have been suggested in both hemispheres from the $\mathrm{Pa}$ leocene onward, as well as a significant lowering of moisture levels at middle latitudes (e.g., Uemura 1997). A combination of these most likely led to the decline and near disappearance of Ginkgo from the Northern Hemisphere during the PaleoceneNeogene. Villar de Seoane et al. (2015, p. 359) stated that "during the Neogene, the climatic conditions of most of Asia and North America changed, but less so in southeastern Asia (in- cluding southern China), where warmer and wetter conditions were maintained and therefore helped to protect Ginkgo during the Quaternary."

\section{Acknowledgements}

We wish to express our gratitude to Natalya Nosova, Komarov Botanical Institute, St. Petersburg, Russian Federation; Eugenia Bugdaeva, Institute of Biology and Soil Science of the RAS, Vladivostok, Russian Federation; and Natalia Zavialova and Eugeny Karasev, Borissiak Paleontological Institute of the RAS, Moscow, Russian Federation, for their help in acquiring rare Russian literature. We also wish to thank two anonymous reviewers for constructive insights and helpful comments on the manuscript.

\section{Literature Cited}

Akagi T 1954 On the Triassic plants from the Hongai coalfield in Tonkin, Indo-China. Nat Sci Rept Ochanomizu Univ 5:153-174. Anderson JM, HM Anderson 1989 Paleoflora of southern Africa, Molteno Formation (Triassic). 2. Gymnosperms (excluding Dicroidium). Balkema, Rotterdam.

2003 Heyday of the gymnosperms: systematics and biodiversity of the Late Triassic Molteno fructifications. Strelitzia 15:1-398. Ash SR 1976 The systematic position of Eogingkoites. Am J Bot 63:1327-1331.

1980 Upper Triassic floral zones of North America. Pages 153-170 in DL Dilcher, TN Taylor, eds. Biostratigraphy of fossil plants. Dowden, Hutchinson \& Ross, Stroudsburg, PA.

1989 The upper Triassic Chinle flora of the Zuni Mountains, New Mexico. Pages 225-230 in OJ Anderson, SG Lucas, DW Love, SM Cather, eds. Southeastern Colorado Plateau: New Mexico Geological Society 40th Annual Fall Field Conference Guidebook. New Mexico Geological Society, Socorro.

2010 Late Triassic ginkgoaleans of North America. Pages 137-185 in CT Gee, ed. Plants in Mesozoic time. Indiana University Press, Bloomington.

Ash SR, HJ Basinger 1991 A high latitude Upper Triassic flora from the Heiberg Formation, Sverdrup Basin, Arctic Archipelago. Geol Surv Can Bull 412:101-131.

Austen PA, DJ Batten 2011 Plant megafossils. Pages 596-642 in DJ Batten, ed. Field guide to fossils: English Wealden fossils. Palaeontological Association Field Guides to Fossils, no. 14. Palaeontological Association, London.

Axsmith BJ, TN Taylor, T Delevoryas, RC Hope 1995 A new species of Eoginkgoites from the Upper Triassic of North Carolina, USA. Rev Palaeobot Palynol 85:189-198.

Axsmith BJ, TN Taylor, EL Taylor 1998 Anatomically preserved leaves of the conifer Notophytum krauselii (Podocarpaceae) from the Triassic of Antarctica. Am J Bot 85:704-713.

Barbacka M 2002 The Jurassic Ginkgoales from the Mecsek Mountains, Hungary. Rev Paleobiol 21:697-715.

Barbacka M, G Pacyna, A Feldman-Olszewska, J Ziaja, E Bodor 2014 Triassic-Jurassic flora of Poland; floristical support of climatic changes. Acta Geol Pol 64:281-308.

Bauer K, E Kustatscher, M Krings 2013 The ginkgophytes from the German Kupferschiefer (Permian), with consideration on the taxonomic history and use of Baiera and Sphenobaiera. Bull Geosci 88: 539-556.

Bibby CJ, NJ Collar, MJ Crosby, MF Heath, C Imboden, TH Johnson, AJ Long, AJ Stattersfield, SJ Thirgood 1992 Putting biodiversity on the map: priority areas for global conservation. International Council for Bird Preservation, Cambridge.
Bose MN, J Banerjee 1984 The fossil floras of Kachchh I. Mesozoic megafossils. Palaeobotanist 33:1-189.

Bose MN, SB Manum 1990 Mesozoic conifer leaves with 'Sciadopityslike' stomatal distribution: a re-evaluation based on fossils from Spitsbergen, Greenland and Baffin Island. Skrifter, no. 192. Norsk Polarinstitutt, Oslo. $81 \mathrm{pp}$.

Bugdaeva EV 1983 A new leaf genus from the Cretaceous sediments of eastern Transbaikalia. Pages 44-47 in VA Krassilov, ed. Palaeobotany and phytostratigraphy of the Far East of the USSR. Akademia Nauk SSSR, Vladivostok.

Burnham RJ 1986 Foliar morphological analysis of the Ulmoideae (Ulmaceae) from the early Tertiary of western North America. Palaeontogr Abt B Palaeophytol 201:135-167.

Chen F, XY Meng, SQ Ren, CL Wu 1988 The early Cretaceous flora of Fuxin Basin and Tiefa Basin, Liaoning Province. Geological Publishing House, Beijing. (In Chinese.)

Chure DJ, R Litwin, ST Hasiotis, E Evanoff, K Carpenter 2006 The fauna and flora of the Morrison Formation: 2006. Pages 233-249 in JR Foster, SGRM Lucas, eds. Paleontology and geology of the Upper Jurassic Morrison Formation. Bulletin 36. New Mexico Museum of Natural History and Science, Albuquerque.

CEPF (Critical Ecosystem Partnership Fund) 2002 Ecosystem profile: mountains of southwest China hotspot. Critical Ecosystem Partnership Fund/Conservation International, Arlington, VA. Published June 12, 2002; accessed March 5, 2015. http://www.cepf.net /Documents/Final.China.SouthwestChina.EP.pdf.

2014 Mountains of Central Asia. Critical Ecosystem Partnership Fund/Conservation International, Arlington, VA. Accessed March 5, 2015. http://www.cepf.net/resources/hotspots/Europe -and-Central-Asia/Pages/Mountains-of-Central-Asia.aspx.

Dallmann WK, T Kjærnet, A Nøttvedt 2001 Geological map of Svalbard 1:100,000. Sheet C9G Adventdalen (explanatory text). Norwegian Polar Institute, Tromsø.

Del Fueyo GM, L Villar de Seoane, S Archangelsky, G Guignard 2006 Estudios cuticulares de Ginkgoites Seward del Cretácico Inferior de Patagonia. Rev Mus Argent Cienc Nat, NS, 8:143-149.

Denk T, RM Dillhoff 2005 Ulmus leaves and fruits from the EarlyMiddle Eocene of northwestern North America: systematics and implications for character evolution within Ulmaceae. Can J Bot 83: 1663-1681.

Denk T, D Velitzelos 2002 First evidence of epidermal structures of Ginkgo from the Mediterranean Tertiary. Rev Palaeobot Palynol 120:1-15.

Denk T, L Wanntorp, SB Manum 1999 Catalogue of the Tertiary plant fossils from Spitsbergen housed in the Swedish Museum of Natural History, Stockholm. Swedish Museum of Natural History, Stockholm. 
Dobruskina IA 1980 Stratigraphic position of the plant-bearing beds of Eurasia. Tr Geol Inst Akad Nauk SSSR 346:1-164. (In Russian.)

1994 Triassic plants of Eurasia. Springer, Vienna.

1998 Lunz flora in the Austrian alps - a standard for Carnian floras. Palaeogeogr Palaeoclimatol Palaeoecol 143:307-345.

Doludenko MP, ES Rasskazova 1972 Ginkgoalean and czekanowskialean plants from the Irkutsk Basin. Pages 7-33 in VA Vakhrameev, ed. Mesozoic plants (ginkgoaleans and czekanowskialeans) of East Siberia. Nauka, Moscow. (In Russian.)

Douglas JG 1970 Ginkgoites multiloba: a new Ginkgo-like leaf. Min Geol J 6:28-31.

Doweld AB 2000 Arberophyllum - a new generic name for Glossophyllum Kräusel, 1943 (Ginkgophyta). Paleontol Zh 6:93-94. (In Russian.)

Duan S 1987 The Jurassic flora of Zhaitang, Western Hills of Beijing. $\mathrm{PhD}$ thesis, University of Stockholm.

Dypvik H, S Hvoslef, T Bjærke, E Finnerud 1985 The Wilhelmøya Formation (Upper Triassic-Lower Jurassic) at Bohemanflya, Spitsbergen. Polar Res, NS, 3:155-165.

Escapa IH, EL Taylor, R Cúneo, B Bomfleur, J Bergene, R Serbet, TN Taylor 2011 Triassic floras of Antarctica: plant diversity and distribution in high palaeolaitude communities. Palaios 26:522544.

Florin R 1936a Die fossilen Gingkophyten aus Franz-Joseph-Land nebst Erörterungen über vermeintliche Cordaitales mesozoischen Alters. I. Spezieller Teil. Palaeontogr Abt B Palaeophytol 81:71-173.

1936b Die fossilen Gingkophyten aus Franz-Joseph-Land nebst Erörterungen über vermeintliche Cordaitales mesozoischen Alters. II. Allgemeiner Teil. Palaeontogr Abt B Palaeophytol 82:1-72.

Gardner JS 1883-1886 A monograph of the British Eocene flora. Vol 2. Gymnospermae. Palaeontographical Society, London.

Givulescu R 1973 Die fossilen Koniferen des Fundortes Chiuzbaia F. Pages 31-35 in R Givulescu, E Olos, eds., Paläobotanische Studien im Tertiär Siebenbürgens. Memorii (Institutul Geologic), no. 19. Geologisches Institut, Bucharest.

Gjelberg JG, RJ Steel 1995 Helvetiafjellet Formation (BarremianAptian, Spitsbergen: characteristics of a transgressive succession. Pages 571-593 in RJ Steel, ed. Sequence stratigraphy on the northwest European margin. NPF (Norsk Petroleumsforening) Spec Publ, no. 5. Elsevier, Amsterdam.

Golovneva LB 2010 Variability in epidermal characters of Ginkgo tzagajanica Samylina (Ginkgoales) from the Paleocene of the Tsagayan Formation (Amur region) and the taxonomy of Tertiary species of Ginkgo. Paleontol J 44:584-594.

Gothan W 1914 Die unter-liassische (rhätische) Flora der Umgegend von Nürnberg. Abh Naturhist Ges Nürnberg 19:91-186.

Hably L, Z Kvaček 1997 Early Pliocene plant megafossils from the volcanic area in West Hungary. Pages 5-51 in L Hably, ed. Early Pliocene volcanic environment, flora and fauna from Transdanubia, West Hungary. Hungarian Natural History Museum, Budapest.

Harland WB, ed 1997 The geology of Svalbard. Geological Society, London.

Harris TM 1935 The fossil flora of Scoresby Sound, East Greenland. 4. Ginkgoales, Coniferales, Lycopodiales and isolated fructifications. Medd Gronl 112:1-176.

1951 The fructification of Czekanowskia and its allies. Philos Trans R Soc B 235:483-508.

1976 The Mesozoic gymnosperms. Rev Palaeobot Palynol 21: 119-134.

Harris TM, J Miller 1974 The Yorkshire Jurassic flora. IV. 2. Czekanowskiales. British Museum (Natural History), London.

Harris TM, W Millington 1974 The Yorkshire Jurassic flora. IV. 1. Ginkgoales. British Museum (Natural History), London.

Heer O 1868 Flora fossilis arctica: die fossile flora der Polarländer enthaltend die in Nordgrönland, auf der Melville-Insel, im Banksland, am Mackenzie, in Island und in Spitzbergen entdeckten fossilen Pflanzen. Mit einem Anhang über versteinerte Hölzer der arktischen Zone von Dr. Carl Cramer. Schulthess, Zurich.

1870 Die miozäne Flora und Fauna Spitzbergens. Mit einem Anhang über die diluvialen Ablagerungen Spitzbergens. K Sven Vetenskapsakad Handl 8:1-98.

1874a Die Kreide-Flora der arctischen Zone. K Sven Vetenskapsakad Handl 12:1-138.

$1874 b$ Ueber Ginkgo Thunbrg. Gartenflora 23:260-262.

$1876 a$ Beiträge zur fossilen Flora Spitzbergens: gegründet auf die Sammlungen der schwedischen Expedition vom Jahre 1872 auf 1873. Mit einem Anhang: Übersicht der Geologie des Eisfjordes und des Bellsundes von Prof. A. E. Nordenskiöld. K Sven Vetenskapsakad Handl 14:1-141.

$1876 b$ Beiträge zur Jura-Flora Ostsibiriens und des Amurlandes. Mem Acad Imp Sci St Petersbg, VIIe Ser, 22:1-122.

1877 Über Pflanzenversteinerungen von Andö in Norwegen. Pt 3 in Flora fossilis Arctica: die fossile Flora der Polarländer. Vol 4. Wurster, Zurich.

- 1878a Die miozäne Flora des Grinnell-Landes. Pages 1-38 in Flora fossilis Arctica: die fossile Flora der Polarländer, Vol 5. Wurster, Zurich.

- $1878 b$ Beiträge zur fossilen Flora Sibiriens und des Amurlandes. Mem Acad Imp Sci St Petersbg, VIIe Ser, 25(6):1-58.

$1878 c$ Primitiae florae fossilis Sachalinensis. Miozäne Flora der Insel Sachalin. Mem Acad Imp Sci St Petersbg, VIIe Ser, 25 (7):1-61.

1881 Zur Geschichte der Ginkgo-artigen Bäume. Bot Jahrb Syst Pflanzengesch Pflanzengeogr 1:1-13.

Holmes WBK, HM Anderson 2007 The Middle Triassic megafossil flora of the Basin Creek Formation, Nymboida Coal Measures, New South Wales. Part 6. Ginkgophyta. Proc Linn Soc NSW 128: 155-200.

Horiuchi J, T Kimura 1986 Ginkgo tzagajanica Samylina from the Paleogene Noda Group, northeast Japan, with special reference to its external morphology and cuticular features. Trans Palaeont Soc Jpn 12:341-353.

Hounslow MW, M Hu, A Mørk, JO Vigran, W Weitschat, MJ Orchard 2007 Magneto-biostratigraphy of the Middle to Upper Triassic transition, central Spitsbergen, Arctic Norway. J Geol Soc (Lond) 164:581-597.

Huang ZG, HC Zhou 1980 Fossil plants. Pages 43-114 in Institute of Geology CAGS, ed. The Mesozoic stratigraphy and paleontology of Shaanxi-Gansu-Ningxia Basin. Institute of Geology CAGS, Beijing. (In Chinese.)

Jordanov D, B Kitanov 1963 Njakolko interesni fosilni rastenija ot pliocena Gocedelčevsko. Ann Univ Sofia Fac Biol Geol Geochim 56:25-37.

Kimura T, M Tsujii 1984 Early Jurassic plants in Japan. Part 6. Trans Proc Palaeont Soc Jpn, NS, 133:265-287.

Kirchner M, JHA van Konijnenburg-van Cittert 1994 Schmeissneria microstachys (Presl, 1833) Kirchner et Van Konijnenburg-van Cittert, comb. nov. and Karkenia hauptmanii Kirchner et Van Konijnenburgvan Cittert, sp. nov., plants with ginkgoalean affinities from the Liassic of Germany. Rev Palaeobot Palynol 83:199-215.

Kiritchkova AI 1969 The materials for the study of the Lower Mesozoic flora of the eastern Urals. Tr VNIGRI (Palaeontol Sb) 268(4): 270-349. (In Russian.)

Kiritchkova AI, NV Nosova 2009 The genus Pseudotorellia Florin (Ginkgoales): taxonomic and stratigraphic aspects. Stratigr Geol Correl 17:615-631.

2012 Jurassic continental deposits of the Middle-Caspian Basin. 2: facies, taphonomy, interregional correlations, flora (Pinophyta: Pteridospermae, Cycadales, Bennettitales, Ginkgoales, Czekanowskiales, Coniferales). VNIGRI (All-Russia Petroleum Research Ex- 
ploration Institute), St. Petersburg. (In Russian with English summary and descriptions of new taxa.)

Kolakovski AA 1964 A Pliocene flora of the Kodor River. Georgian Acad Sci Monogr 1:1-209.

Kostina EI, AB Herman 2013 The Middle Jurassic flora of South Mongolia: composition, age and phytogeographic position. Rev Palaeobot Palynol 193:82-98.

Kovar-Eder J 1988 Obermiozäne (Pannone) Floren aus der Molassezone Österreichs. Beitr Palaeontol Oesterr 14:19-121.

Krassilov VA 1970 Approach to the classification of Mesozoic "ginkgoalean" plants from Siberia. Palaeobotanist 18:12-19.

1972 Mesozoic flora from the Bureja River (Ginkgoales and Czekanowskiales). Nauka, Moscow. (In Russian.)

1982 Early Cretaceous flora of Mongolia. Palaeontogr Abt B Palaeophytol 181:1-43.

Kräusel R 1943 Die Gingkophyten der Trias von Lunz in Niederösterreich und von Neue Welt bei Basel. Palaeontogr Abt B Palaeophytol 87:59-93.

— 1949 Koniferen und andere Gymnospermen aus der Trias von Lunz, Nieder-Österreich. Palaeontogr Abt B Palaeophytol 89:35-82.

Kryshtofovich A, V Prynada 1932 Contributions of the Mesozoic flora of Ussuriland. Bull Un Geol Prosp Serv USSR 51:363-374.

Kvaček Z, SB Manum 1997 A. G. Nathorst's (1850-1921) unpublished plates of Tertiary plants from Spitsbergen. Swedish Museum of Natural History, Stockholm.

Launis A, C Pott, A Mørk 2014 A glimpse into the Carnian: Late Triassic plant fossils from Hopen, Svalbard. Norw Pet Dir Bull 11: 129-136.

Lesquereux L 1880 Description of the coal flora of Pennsylvania and of the Carboniferous Formation throughout the United States. Vol 2. Board of Commissioners for the Second Geological Survey, Harrisburg, PA.

Li PJ, YL He, XW Wu, SW Mei, BY Li 1988 Early and Middle Jurassic strata and their floras from northeastern border of Qaidam Basin, Qinghai. Nanjing University Press, Nanjing. (In Chinese with English summary.)

Li XX, ed 1995 Fossil flora of China through the geological ages. Guangdong Science and Technology Press, Guangzhou.

Lin X 2007 Natural populations and plantation areas of Ginkgo biloba. Pages 37-52 in FL Cao, ed. A monograph of Chinese ginkgos. China Forestry Publishing House, Beijing. (In Chinese.)

Linnæus C 1771 Mantissa plantarum altera generum editionis VI. \& specierum editionis II. Laurentiisalvii, Stockholm (Holmiæ).

Lundblad B 1957 On the presence of the genus Pseudotorellia (Ginkgophyta) in the Rhaetic of N. W. Scania. Geol Foeren Stockh Foerh 79:759-765.

1959 Studies in the Rhaeto-Liassic floras of Sweden. II:1Ginkgophyta from the mining district of NW Scania. K Sven Vetenskapsakad Handl, 4th Ser, 6:1-38.

1968 The present status of the genus Pseudotorellia Florin (Ginkgophyta). J Linn Soc Lond Bot 61:189-195.

Lydon SJ, J Watson, NA Harrison 2003 The lectotype of Sphenobaiera ikorfatensis (Seward) Florin, a ginkgophyte from the Lower Cretaceous of western Greenland. Palaeontology 46:413-421.

Manum SB 1963 Notes on the Cretaceous-Tertiary boundary in Baslikaen, Vestspitsbergen, and a new record of Ginkgo from the Spitsbergen Tertiary. Nor Polarinst Arbok 1962:149-152.

1966 Ginkgo spitsbergensis n. sp. from the Paleocene of Spitsbergen and a discussion of certain Tertiary species of Ginkgo from Europe and North America. Nor Polarinst Arbok 1965:49-58.

Manum SB, MN Bose, JO Vigran 1991 The Jurassic flora of Andøya, northern Norway. Rev Palaeobot Palynol 68:233-256.

McIver EE, JF Basinger 1993 Flora of the Ravenscrag Formation (Paleocene), southwestern Saskatchewan, Canada. Palaeontogr Can 10:1-167.
Miller CN 1987 Land plants of the northern Rocky Mountains before the appearance of flowering plants. Ann Mo Bot Gard 74: 692706.

Mørk A 1978 Observations on the stratigraphy and structure of the inner Hornsund area. Norsk Polarinst Arbok 1977:61-70.

Mørk A, R Knarud, D Worsley 1982 Depositional and diagenetic environments of the Triassic and Lower Jurassic succession of Svalbard. Pages 371-398 in AR Embry, HR Balkwill, eds. Arctic geology and geophysics: Proceedings of the Third International Symposium on Arctic Geology. Memoir 8. Canadian Society of Petroleum Geologists, Calgary.

Mustoe GE 2002 Eocene Ginkgo leaf fossils from the Pacific Northwest. Can J Bot 80:1078-1087.

Nathorst AG 1878-1886 Om floran i Skånes kolförande bildningar. Sver Geol Undersokn C 27, 33, 85:1-126.

1897 Zur mesozoischen Flora Spitzbergens. K Sven Vetenskapsakad Handl 30:1-77.

1910 Beiträge zur Geologie der Bären-Insel, Spitzbergens und des König-Karl-Landes. Almqvist \& Wiksell, Uppsala.

1919 Ginkgo adiantoides (Unger) Heer im Tertiär Spitzbergens nebst einer kurzen Übersicht der übrigen fossilen Ginkgophyten desselben Landes. Geol Foeren Stockh Foerh 41:233248.

1921 Zur tertiären Flora Spitzbergens. Unfinished manuscript (only plates 1-37 were printed at the time of Nathorst's death) in the collections of the paleobotanical library of the Swedish Museum of Natural History, Stockholm.

NPI (Norsk Polarinstitutt) 2015a Geologiske kart, map EF1011G. Norsk Polarinstitutt, Tromsø. http://www.npolar.no/no/tjenester/kart /trykte/geologiske-svalbard.html. Accessed March 4, 2015.

$2015 b$ The place names of Svalbard 1942-2015. Norsk Polarinstitutt, Tromsø. http://stadnamn.npolar.no. Accessed March 4, 2015.

Ôishi S 1938 On the cuticles of Tertiary Ginkgoites leaves from Kuzi, Iwate Prefecture. J Fac Sci Hokkaido Univ Ser IV Geol Mineral 4:103-106.

1940 The Mesozoic floras of Japan. J Fac Sci Hokkaido Univ Ser IV Geol Mineral 5:123-480.

Orlovskaya ER 1979 The Triassic flora of Burluk River (Kazakhstan). Dep. 10.05.79. No. 1669. VINITI: Moscow. 75 pp. (In Russian.)

Parker JR 1967 The Jurassic and Cretaceous sequence in Spitsbergen. Geol Mag 104:487-505.

Pole MS, JG Douglas 1999 Bennettitales, Cycadales, and Ginkgoales from the Mid-Cretaceous of the Eromanga Basin, Queensland, Australia. Cretac Res 20:523-538.

Pomel A 1849 Matériaux pour servir à la flore fossile des terrains jurassiques de la France. Pages 332-354 in JPJ Monheim, MH Debey, eds. Amtlicher Bericht über die 25. Versammlung der Gesellschaft deutscher Naturforscher und Ärzte in Aachen im September 1847. Beaufort, Aachen.

Pott C 2007 Cuticular analysis of gymnosperm foliage from the Carnian (Upper Triassic) of Lunz, Lower Austria. PhD thesis, University of Münster.

_ 2014a A revision of Wielandiella angustifolia, a shrub-sized bennettite from the Rhaetian-Hettangian of Scania, Sweden, and Jameson Land, Greenland. Int J Plant Sci 175:467-499.

$2014 b$ The Triassic flora of Svalbard. Acta Palaeontol Pol 59:709-740.

Pott C, B Axsmith 2015 Williamsonia carolinensis sp. nov. and associated Eoginkgoites foliage from the Upper Triassic Pekin Formation: implications for early evolution in Williamsoniaceae (Bennettitales). Int J Plant Sci 176:174-185.

Pott C, M Guhl, J Lehmann 2014 The Early Cretaceous flora from the Wealden facies at Duingen, Germany. Rev Palaeobot Palynol 201:75-105. 
Pott C, M Krings 2010 Gymnosperm foliage from the Upper Triassic of Lunz, Lower Austria: an annotated checklist and identification key. Geo.Alp 7:19-38.

Pott C, M Krings, H Kerp 2007 A surface micro-relief on the leaves of Glossophyllum florinii (?Ginkgoales) from the Upper Triassic of Lunz, Austria. Bot J Linn Soc 53:87-95.

2008 The Carnian (Late Triassic) flora from Lunz in Lower Austria: palaeoecological considerations. Palaeoworld 17:172-182.

Pott C, A Launis 2015 Taeniopteris novomundensis sp. nov.- “cycadophyte" foliage from the Carnian of Switzerland and Svalbard reconsidered: how to use Taeniopteris? N Jahrb Geol Palaeont Abh 275:19-31.

Pott C, S McLoughlin 2009 Bennettitalean foliage in the RhaetianBajocian (latest Triassic-Middle Jurassic) floras of Scania, southern Sweden. Rev Palaeobot Palynol 158:117-166.

Pott C, S McLoughlin, A Lindström, S Wu, EM Friis 2012 Baikalophyllum lobatum and Rehezamites anisolobus: two seed plants with "cycadophyte" foliage from the Early Cretaceous of eastern Asia. Int J Plant Sci 173:192-208.

Prynada VD 1962 Mesozoic flora of eastern Siberia and Transbaikalia. Gosgeolltekhizdat, Moscow. (In Russian.)

Rønning OI 1996 The flora of Svalbard. Norsk Polarinstitutt, Tromsø. Quan C, G Sun, Z Zhou 2010 A new Tertiary Ginkgo (Ginkgoaceae) from the Wuyun Formation of Jiayin, Heilongjiag, northeastern China and its paleoenvironmental implications. Am J Bot 97:446-457.

Samylina VA $1956 a$ The epidermal structure of the leaves of the genus Sphenobaiera. Dokl Akad Nauk SSSR 106:537-539. (In Russian.)

$1956 b$ New cycadophytes in Mesozoic deposits of the Aldan River. Bot Zh 41:1334-1339. (In Russian.)

1963 The Mesozoic flora of the lower course of the Aldan River. Paleobotanica 4:59-139. (In Russian with English summary.)

1967 On the final stage of the history of the genus Ginkgo L. in Eurasia. Bot Zh 52:303-316. (In Russian.)

1974 Early Cretaceous flora of northeastern USSR. Komarovskie Chteniya 27:1-56. (In Russian.)

Samylina VA, AI Chelebayeva 1986 New data on the Tertiary species of Ginkgo in Soviet eastern Asia. Palaeont J 20:91-96.

Sandbakk BE 2015 The flora of Svalbard. http://svalbardflora.no. Accessed February 4, 2015.

Saporta, G 1873 Paléontologie française ou description des fossiles de la France. Deuxième série—végétaux: plantes jurassiques. Masson, Paris.

Schenk A 1865-1867 Die fossile Flora der Grenzschichten des Keupers und Lias Frankens. Kreidel, Wiesbaden.

1871 Die fossile Flora der nordwestdeutschen Wealdenformation. Fischer, Kassel.

Schimper WP 1874 Traité de paléontologie végétale ou la flore du monde primitif dans ses rapports avec les formations géologiques et la flore du monde actuel. Baillière, Paris.

Schloemer-Jäger A 1958 Alttertiäre Pflanzen aus Flözen der BroggerHalbinsel Spitsbergens. Palaeontogr Abt B Palaeophytol 104:39103.

Schweitzer HJ 1974 Die “tertiären” Koniferen Spitzbergens. Palaeontogr Abt B Palaeophytol 169:1-89.

Schweitzer HJ, M Kirchner 1995 Die Rhäto-Jurassischen Floren des Iran und Afghanistans. 8. Ginkgophyta. Palaeontogr Abt B Palaeophytol 237:1-58.

Seward AC 1919 Fossil plants: a text-book for students of botany and geology. Vol IV. Ginkgoales, coniferales, gnetales. Cambridge University Press, Cambridge.

Sharma BD 1974 The Jurassic flora of the Rajmahal Hills, Indiaadvances and challenges. Acta Palaeobot 15:3-15.

Shen L, XY Chen, X Zhang, YY Li, CX Fu, YX Qiu 2005 Genetic variation of Ginkgo biloba L. (Ginkgoaceae) based on cpDNA PCRRFLPs: inference of glacial refugia. Heredity 94:396-401.
Shorokhova SA 1997 Late Triassic floras in the Primorye Region, Russia. Pages 109-119 in A Baud, I Popova, JM Dickins, SG Luca, Y Zakharov, eds. Late Paleozoic and Early Mesozoic circum-Pacific events: biostratigraphy, tectonics and ore deposits of Primorye (Far East Russia). Mémoires de Géologie (Lausanne), no. 30. Swiss Academy of Sciences, Lausanne.

Sixtel TA 1962 Flora of the Late Permian and Early Triassic in southern Fergana. Pages 271-414 in Stratigraphy and palaeontology of Uzbekistan and adjacent areas. Akademia Nauk USSR, Tashkent. (In Russian.)

Steel RJ, J Gjelberg, G Haarr 1978 Helvetiafjellet Formation (Barremien) at Festningen, Spitsbergen - a field guide. Norsk Polarinst Arbok 1977:111-128.

Szafer W 1961 Miocene flora from Stare Gliwice in Upper Silesia. Prace, no. 33. Geological Institute, Warsaw. 205 pp. (In Polish.)

Sze HC 1956 Older Mesozoic plants from the Yenchang Formation, northern Shensi. Palaeontol Sin, NS A, 139(5):1-217.

Taylor TN, EL Taylor, M Krings 2009 Paleobotany: the biology and evolution of fossil plants. Academic Press, Burlington, MA.

Tozer ET, JR Parker 1968 Notes on the Triassic biostratigraphy of Svalbard. Geol Mag 105:526-542.

Tralau H 1968 Evolutionary trends in the genus Ginkgo. Lethaia 1: 63-101.

Uemura K 1997 Cenozoic history of Ginkgo in East Asia. Pages 207221 in T Hori, RW Ridge, W Tulecke, P del Tredici, J TrémouillauxGuiller, HTobe, eds. Ginkgo biloba - a global treasure: from biology to medicine. Springer, Tokyo.

Unger F 1845 Synopsis plantarum fossilium. Leopold Voss, Leipzig. 1850 Genera et species plantarum fossilium. Wilhelm Braumüller, Vienna.

Vakhrameev VA 1991 Jurassic and Cretaceous floras and climates of the earth. Cambridge University Press, Cambridge.

Vakhrameev VA, MP Doludenko 1961 Upper Jurassic and Lower Cretaceous flora from the Bureja Basin and their stratigraphic significances. Tr Geol Inst Akad Nauk SSSR 54:1-136. (In Russian.)

Van Konijnenburg-van Cittert JHA, HS Morgans 1999 The Jurassic flora of Yorkshire. Palaeontological Association, London.

Van Konijnenburg-van Cittert JHA, J van der Burgh 1989 The flora from the Kimmeridgian (Upper Jurassic) of Culgower, Sutherland, Scotland. Rev Palaeobot Palynol 61:1-51.

Vasilevskaya ND 1972 The Late Triassic flora of Svalbard. Pages 27-63 in VN Sokolova, ND Vasilevskaya, eds. Mezozojskie otloženiâ Sval'barda. NIIGA (Research Institute of Arctic Geology), Leningrad. (In Russian.)

1980 The Early Cretaceous flora of the Spitsbergen Island. Pages 61-69 in DV Semevskii, ed. Geology of the sedimentary platform of the Svalbard archipelago. NIIGA (Research Institute of Arctic Geology), Leningrad. (In Russian.)

1983 The Late Triassic plants from the island of Hopen (Svalbard). Pages 142-149 in AA Krasilskkov, VA Basov, eds. Geologiâ Špicbergena. Ministerstvo geologii SSSR, PGO "Sevmorgeologia," Leningrad. (In Russian.)

Vavrek MJ, HCE Larsson, N Rybczynski 2007 A Late Triassic flora from east-central Axel Heiberg Island, Nunavut, Canada. Can J Earth Sci 44:1653-1659.

Velitzelos D, T Denk 2002 First evidence of epidermal structures of Ginkgo from the Mediterranean Tertiary. Rev Palaeobot Palynol 120:1-15.

Vigran JO, G Mangerud, A Mørk, D Worsley, PA Hochuli 2014 Palynology and geology of the Triassic succession of Svalbard and the Barents Sea. Spec Publ, no. 14. Geological Survey of Norway, Oslo. 270 pp.

Villar de Seoane L, NR Cúneo, I Escapa, P Wilf, MA Gandolfo 2015 Ginkgoites patagonica (Berry) comb. nov. from the Eocene of Patagonia, last ginkgoalean record in South America. Int J Plant Sci 176:346-363. 
Volynets EB, SA Shorokhova, Sun G 2008 Late Triassic flora of the Partizanskaya River Basin (southern Primor'e). Stratigr Geol Correl 16:47-58.

Watson J 1969 A revision of the English Wealden flora, I. CharalesGinkgoales. Bull Br Mus Nat Hist (Geol) 17:207-254.

Watson J, KA Alvin 1996 An English Wealden floral list, with comments on possible environmental indicators. Cretac Res 17:5-26.

Watson J, NA Harrison 1998 Abietites linkii (Römer) and Pseudotorellia heterophylla Watson: coniferous or ginkgoalean? Cretac Res 19:239-278.

Watson J, SJ Lydon, NA Harrison 1999 Consideration of the genus Ginkgoites Seward and a redescription of two species from the Lower Cretaceous of Germany. Cretac Res 20:719-734.

Wu SQ 1999 A preliminary study of the Jehol flora from western Liaoning. Palaeoworld 11:7-57. (In Chinese with English abstract.) - 2003 Land plants. Pages 166-177 in M Chang, P Chen, Y Wang, Y Wang, D Miao, eds. The Jehol Biota: the emergence of feathered dinosaurs, beaked birds and flowering plants. Scientific and Technical Publishers, Shanghai. (In Chinese.)

Zeiller R 1903 Flore fossile des gîtes de charbon du Tonkin. Ministère des Travaux Publics, Paris.

Zhao M, CL Sun, DL Dilcher, YL Na, DH Xing 2015 A new species of Baiera from the Early Cretaceous Jehol Biota of southeastern Jilin, China. Palaeoworld (forthcoming). doi:10.1016/j.palwor.2015.01.001.
Zheng S, N Li, Y Li, W Zhang, X Bian 2005 A new genus of fossil cycads Yixianophyllum gen. nov. from the Late Jurassic Yixian Formation, western Liaoning, China. Acta Geol Sin 79:582-592.

Zhou HQ 1981 Discovery of the Upper Triassic flora of Yangcaogou of Beipiao, Liaoning. Pages 147-152 in Twelfth Annual Conference of the Palaeontological Society of China, selected papers. (In Chinese.)

Zhou ZY 1991 Phylogeny and evolutionary trends of Mesozoic ginkgoaleans-a preliminary assessment. Rev Palaeobot Palynol 68:203216.

1997 Mesozoic ginkgoalean megafossils: a systematic review. Pages 183-206 in T Hori, RW Ridge, W Tulecke, P del Tredici, J Trémouillaux-Guiller, H Tobe, eds. Ginkgo biloba-a global treasure: from biology to medicine. Springer, Tokyo.

2009 An overview of fossil Ginkgoales. Palaeoworld 18:1-22.

Zhou ZY, C Quan, YS Liu 2012 Tertiary Ginkgo ovulate organs with associated leaves from North Dakota, U.S.A., and their evolutionary significance. Int J Plant Sci 173:67-80.

Zhou ZY, XW Wu 2006a Early Mesozoic radiation and diversification of ginkgoaleans. Pages 519-549, 904-906 in JY Rong, ZJ Fang, ZH Zhou, RB Zhan, XD Wang, XL Yuan, eds. Originations, radiations and biodiversity changes - evidences from the Chinese fossil record. Science Press, Beijing. (In Chinese with English summary.)

$2006 b$ The rise of ginkgoalean plants in the early Mesozoic: a data analysis. Geol J 41:363-375. 